\title{
Aspectos de la indemnidad en la Constitución española de 1978
}

\author{
Manuel María Zorrilla Ruiz \\ Catedrático Emérito de la Universidad de Deusto \\ Ex-Presidente del Tribunal Superior de Justicia del País Vasco \\ Presidente de la Asociación de Jueces y Magistrados Jubilados de España
}

A la memoria de mi mujer, Marisol, con el recuerdo que el paso de los días hace más indeleble y dolorido

\begin{abstract}
Sumario: 1. Introducción.-2. Garantía de la indemnidad inherente a la nota de plenitud del ordenamiento jurídico.-3. Garantía de la indemnidad fundada en el desarrollo de exigencias constitucionales implícitas. - 4. Tutela de la indemnidad a cargo del valor superior del pluralismo político.-5. Garantía de la indemnidad fundada en la presunción de justicia material y no sólo de la estricta validez del ordenamiento jurídico.-6. ¿Constitucionalidad o constitucionalización del uso alternativo del Derecho?.-7. Manifestaciones notables y específicas de la indemnidad patrimonial. - 8. Garantía de la indemnidad forjada en la defensa sistemática del futuro de la persona individual.
\end{abstract}

\section{INTRODUCCIÓN}

Las reflexiones siguientes pretenden exponer -desde una perspectiva mejorable y sensata- una noción de indemnidad distribuida en varios aspectos, a saber: Primero. Garantía de la indemnidad inherente a la plenitud del ordenamiento jurídico. Segundo. Garantía de la indemnidad facilitada por la presunción de justicia y no de simple validez de las normas de dicho ordenamiento. Tercero. Garantía de la indemnidad ofrecida por las repercusiones constitucionales del Derecho de daños. Cuarto. Garantía de la indemnidad ideada por el Estado de Bienestar para amparar el futuro de la persona individual.

\section{GARANTÍA DE LA INDEMNIDAD INHERENTE A LA NOTA DE PLENITUD DEL ORDENAMIENTO JURÍDICO}

El ordenamiento jurídico del Estado social y democrático de Derecho despierta las tensiones robustecedoras de la plenitud que, aderezando la seguridad jurídica garantizada en el art. 9.3 CE (Constitución española de 27 de diciembre de 1978), reflejan los textos constitucionales y los pasajes cuasiconstitucionales que, como el TPC.c. (Título Preliminar del Código Civil de 24 de julio de 1889, sucedido por la Ley de 31 de mayo de 1974), adornan sus 
principios y preceptos. La voluntad de plenitud y la tendencia a conseguirla -minorando el espectro de las lagunas de la ley- responden a un ánimo de exhaustividad. Se refieren a estados de cosas que -concerniendo a los intereses o apetencias por la utilidad de los bienes sensibles de la vida-reclaman una regulación coherente y clara de sus mandatos y/o prohibiciones.

Esta propensión impide que, antes incluso de verse culminados, los acontecimientos de la vida social de relación muestren las inclemencias e incertidumbres del vacio en las zonas abandonadas o desérticas. Su característica común -resistencia a la recepción del Derecho objetivo y a la penetración de su tutela- esteriliza los esfuerzos que, invertidos en tan enojoso ejercicio, despliegan la persona individual y sus af ines, cuantas veces se responsabilizan de los efectos jurídicos inseparables del signo de los tiempos que les toca vivir. El acreedor de una relación de obligación está legitimado para obrar extra e intraprocesalmente, porque su crédito importa un interés que -lejos de ser huero de sensibilidad y de deseo- abarca un todo mentalmente tangible que aglutina necesidades e ilusiones. La plenitud del ordenamiento jurídico transmite a la persona humana la convicción y los merecimientos de una atribución de dignidad que se ha de preservar a toda costa.

La dignidad es un crédito que el ordenamiento jurídico concede al individuo para beneficiarle de las ofertas que, asediando a su yo ambicioso y expectante, anhelan la mejor de las suertes en el círculo vital que las acoge y aproxima a sus destinatarios. Es la cosmoeminencia que -con lucidez, tenacidad y adecuación existencial- va en pos de una conciliación indispensable. Frecuenta la línea horizontal de la solidaridad -distinta de las definiciones descomprometidas y confusas-y de la comunión con los demás, cuyos enfoques más exactos la denominan reciprocidad. Un valor al que las injerencias globalizadoras despojan de la autenticidad que le acompaña y sirve de acicate. La reciprocidad supone el intercambio de bienes y de ideas en un mundo donde el rostro amable -anverso del rostro diabólico pendiente de una severa exploración- propicia una suma de reconversiones morales. Este paso acusa la hostilidad a las deformaciones de una solidaridad tanto más cómoda de fingir, cuanto más alejado de ella está el prójimo oprimido y el sacrificio de auxiliarle sólo es testimonial por excelencia. Así resulta fácil -debido a esa distancia- confraternizar teóricamente y derrochar, sin arrostrar los riesgos de la heroicidad, las efusiones sentimentales y las afinidades halagüeñas. La dignidad concilia la vocación del socorro mutuo con las prerrogativas de dominación que-como derecho ansiado y obligación transformadora- ejerce el individuo sobre el resto de las cosas y seres dispersos por el mundo. Sus mudanzas se valen de las oportunidades que han de capitalizarse para acabar con el oprobio de unas vidas injustamente consumidas, registradas de antiguo en la necrología de la Historia de la Humanidad, y combatir las contrariedades que -reanudando el raciocinio sobre el problema del mal-oprimen su menesterosa condición. La persona es objeto de una protección acorde con la eminencia de su dignidad y con la supresión del desmerecimiento que 
esas desventuras acarrean. La dignidad, libre de toda invocación superficial, defiende la pulcritud de una imagen que invita a concebirla como algo más categórico y rotundo que la atribución del carácter de derecho fundamental.

La dignidad constituye un paradigma de derecho que, desde la perspectiva del iluminismo y las pautas de la laicidad, pertenece a cada persona individual, no -como antaño se sostuvo- por el hecho de creer en un haz de verdades confesionales reveladas y sí por la cualidad de ser creado que, hastiado de amargura, el existencialismo declaraba caído en este mundo y víctima de sus iniquidades. La dignidad se verifica -como algo previo a dicho reconocimiento- a la manera de una condición innata que, según las circunstancias de las personas del tiempo y del lugar, no escatima las opciones que los postulados del orden natural someten a su aceptación. Con fruición, unas veces, y, otras, con recelos y riesgos. Serían ellas las oportunidades de materializar aquel crédito, de afianzar la conviccion de sus prerrogativas, de contar con los efectivos bastantes para impedir su menoscabo, y de agrandar los espacios de dominación que, para vincularlos a la causa del bien, se arrebatan al poder de las tinieblas. La dignidad personal es la base -como sostiene el art. 10.1 CE- de las indemnidades con que el Derecho objetivo obsequia a la persona para acentuar la prosperidad de los derechos invocados o la calidad de los intereses cuya supervivencia se debate.

Entre las luces y las sombras de un aventurado proyecto, se advierte cómo el cuerpo de la legalidad fundamental evidencia unos designios de indemnidad que, a primera vista, lo son todos, pero que, a la luz de sus medios y sus fines, delatan consecuencias aleccionadoras. La esencia de esta perspectiva atañe al fortalecimiento de las situaciones contempladas por el legislador constituyente y a los casos en que hay que impedir su deterioro. La indemnidad se propone que, en el tejido de las relaciones humanas, decrezcan los ámbitos donde las razones estrictas de la fuerza -dispuestas a cumplir su papel poco airoso- han subvertido las instancias persuasivas del razonamiento, reemplazando, por modos injustos e insolidarios de vivir, la vehemencia expansiva de los espacios hurtados a esas vejaciones. La indemnidad propugna soluciones que fundan su crédito en el ingrediente de fuerza moral -que las hace deseables y evidentes-y en la dosis de razonabilidad que, al facilitar su comprensión, las traslada al terreno del interés que ha engendrado el conflicto.

La confianza en la acción vigilante de un Derecho atento y eficaz incluye situaciones que, pese a embeber la ciencia de la legislación en el marco de un positivismo acogedor, no son invulnerables frente a las agresiones. Algo ha de innovarse, a imagen y semejanza de una tutela judicial efectiva que hoy no abunda en soluciones imaginativas. Ello, sin que decaiga la confianza en que-zarandeados por el excitante «atrévete a pensar»- los avances de la legislación descongelarán, al precio del esfuerzo creativo, los glaciares de la eficacia escueta del Derecho y probarán el tino de su progresismo razonable. 
La esperanza puesta en la justificación de la efectividad del legislador se debe a las variantes de su acción normativa. La primera consiste en agotar o adelantar, con la debida diligencia, el desarrollo legislativo de los mandatos y/o prohibiciones constitucionales cuya eficacia preceptiva directa data de su estirpe de derechos y libertades innatos. Sus fuentes yusnaturalistas y su imposición al arbitrio del legislador se anteponen a las leyes positivas humanas, como un troquel que, sin desordenarlas, conglomera sus materias primas. Es tajante la inmediación con que, sin interposiciones dilatorias, sus proposiciones normativas han de aplicarse a los supuestos pensados para activar las facultades en que su esencia resplandece y cobra nuevos bríos. Esta cualidad no exime a la ciencia de la legislación o Política Legislativa -aliada de las libertades que, al recordar sus atenciones, no le conceden tregua ni respirode la obligación de aderezar, sin contornos borrosos, algunas hipótesis. Son ellas las que-sagazmente adivinadas y/o latentes en las realidades sociales de que se hace mérito- permiten que, en pro del interés correspondiente, se actuen las facultades del derecho atribuido o se cumplan las funciones -sociales asimismo- que su evolución pone de manifiesto. La efectividad de la legislación obliga a una vigilia interminable que restaure, modernice y/o amplíe el contenido esencial o núcleo intangible de los derechos básicos objeto de estudio. ¿Cómo lograrlo satisfactoriamente? Encadenando y completando unas tareas tan arduas como imprescindibles.

Hay que obtener información veraz, por medios lícitos e inocuos para cualquier tercero, de los ciclos evolutivos y de las incidencias que jalonan los procesos de cambio, denunciando los casos de obsolescencia y holganza rutinaria, y activando -como se infiere del art. 20.1 CE- los mecanismos de revisión y puesta al día.

Es preciso inventar-eligiendo modelos practicables y no simulaciones peligrosas- las ejemplificaciones de esas novedades en los horizontes constitutivamente históricos de la razón práctica. Sus dictámenes son pareceres de certeza variable y, a causa del apasionamiento que les acompaña, oscurecen, muchas veces, la predilección de los entendimientos curiosos que pierden las oportunidades de abismarse en sus inquietudes más recientes. Máxime, cuando ciertos oficialismos difunden azarosas versiones de demandas sociales, fruto de la zafiedad y condenadas a un naufragio inminente. Hay que cuidar de que, salvando los contenidos esenciales, no se desvanezcan, se oculten o se pierdan de vista los aspectos accidentales que, concienzudamente cultivados, enriquecen las perspectivas generales y, con ellas, los panoramas que revelan. La fascinación de esos derechos - gracias a su efectividad- determina la entrada en combate que obedece a alguna de las motivaciones expresadas.

Las normas jurídicas constitucionales revestidas de eficacia preceptiva directa, no se reducen a los magros términos de las proposiciones de principio en que sus juicios desembocan. Su importancia y sus eventualidades de futuro se condicen mal con el tenor de las interpretaciones originalistas que, aferradas a las circunstancias del tiempo y del lugar en que se promovieron, 
aplauden su petrificación y rechazan su ajuste a los cambios sociales que inexorablemente se suceden. Lo contrario - pues aquí repugna comulgar con verdades a medias- de la vulgaridad y los radicalismos políticos en que -reiterando una expresión debida a quienes, en 1870, propusieron el modélico lema de «la invención de la Magistratura contemporánea»- incurrían algunas turbas de juristas prestos a confundir, sin asomos de recta intención, las auténticas demandas sociales con los arbitrios de su imaginación desvariada o el buen obedecer que se esperaba de ellos. Una vez más, «no es eso, no es eso». Cada persona física no equivale a ella sola, sino a la suma de si misma y la parte del mundo que la condiciona y acapara, cuando no la inmoviliza y la secuestra. Las normas jurídicas constitucionales, de que se hace cuestión, constan del mensaje impreso por la filosofía del orden natural -fuente de sus orígenes y transformaciones- y de los aditamentos sucesivos que las complementan para cumplir sus condiciones de generalidad y difusión. Uno de dichos añadidos se interna en la comprensión de aquel mensaje para localizar la aparición de elementos implícitos que, a primera vista, se hallan soterrados y brillan con luz propia cuando se exhuman y divulgan comprensiblemente. Otros facilitan útiles o sugieren métodologías cuyas aplicaciones diseñan un panorama de bienes más numerosos y accesibles, obligando a sistemátizar los términos del cumplimiento de esta ocupación. Otros atañen a las operaciones judiciales que, adheridas a un rejuvenecido pensamiento, mejoran el nivel de la seguridad jurídica y espolean los ejercicios de creatividad que, si media un celoso amor a la verdad, enriquecen aquellos contenidos. Aunque el énfasis de las proclamaciones fundamentales dé a entender que, con lo que dicen, todo está dicho sobre su materia o especialidad, el entretejido de la vida social enseña que, sin dejar de ser verdad, se trata de una verdad contemporánea que mantiene la normalidad de su flujo e ilumina los cambios que, a partir de sus puntos de inflexión, se multiplican.

Acatando la cláusula de vinculación general e indistinta que el art. 53.2 $\mathrm{CE}$ predica de los derechos cuasinaturales e innatos, el empeño del legislador y de los jueces ordinarios no sólo ha de favorecer la primacía de la justicia material -resultante de integrar la efectividad de las libertades y de las situaciones de igualdad que jalonan sus experimentos- sin que, por ello, sobreviva un mundo asolado por los actos injustos que aniquilan los incentivos de su cosmovisión. La Política Legislativa y el ejercicio de la jurisdicción deben intentar, hasta la extenuación, que los individuos y los grupos sociales aprecien los alicientes autorreguladores que alientan la viabilidad y animan las interpretaciones de cada situación existencial sobre los derechos reconocidos constitucionalmente. Acogen la multiplicidad-rectius, acaso infinidad- de complementos que les adjudican sus titulares, motivados por la exteriorización de sus respectivos sentimientos constitucionales. Son éstos, hoy por hoy, el subrogado de la antigua impresión de las normas del orden natural en la conciencia individual y de los arrestos con que las potencias del alma -memoria, entendimiento y voluntad- se cercioran de su advenimiento. Al 
convertirlas en un acervo propio, no se olvidan de sus imperativos y los trasladan a los estados de perplejidad o de conflicto en que se vuelca el torrente de verdad que arrastra su luz cegadora. Las ocurrencias de los titulares de esas libertades y derechos, y no menos de sus beneficiarios, constituyen las fuentes que-además de los análisis técnicojurídicos sobre su evolución a través de la Política Legislativa o de la aplicación judicial del Derecho-saturan, fuera de sofismas y contradicciones, los círculos en que el bien integrante de unas y otros tiende a difundirse.

Ambos demuestran una juricidad espontánea que no prospera casualmente y sí gracias al impacto de sus testimonios. Su despliegue apareja un tanto de ductilidad que -al contrario de los seres vivientes que, a costa del envejecimiento, prolongan su existencia- tonifica la modernidad de las normas constitucionales que les reconocen. Las protegen contra la celeridad e inconveniencia de determinados cambios sociales -sin relativizar su eficacia ni ponerlas en trances de esterilidad o de amenaza- y ensayan terapias regeneradoras. Lejos de aminorar la velocidad de crucero de las libertades y derechos, los cambios sociales - que, cada vez, tienen menos de apacibles mudanzas y más de estrepitosas convulsiones- aumentan las reacciones en pro de su supervivencia. El asombro genera tensiones que obligan a frenar las depredaciones cuya proximidad avisa de los riesgos que, a la vuelta de la esquina, aguardan la consigna de entrar en combate.

Se yerra al sostener que una regulación legislativa de las libertades y derechos dotados de eficacia preceptiva directa desnaturaliza su mordiente, empequeñece su arrogancia o acusa una insuficiencia semejante a un «quiero y nо puedo» del constituyente, siendo así que éste ha cumplido su papel y que tales objeciones no se justifican. Las tareas de amplificación y desarrollo -recabadas por la dogmática jurídica, sugeridas por una opinión pública ilustrada y activa, emanadas de las diversas sensibilidades y amparadas en la madurez de los juicios que las patrocinan- no vulneran el contenido esencial de la libertad o el derecho, ni obedecen al fin-expresivo de cierta indigencia intelectual- de cercenar el crecimiento de sus garantías. Descansan en fundamentos firmes y disponen de asideros muy recios. No veda el ejercicio de esas operaciones la protesta solemne de que las libertades y derechos originarios se reconocen obligatoriamente y no se otorgan por condescendencia. Ello es así, porque -contemplando objetivamente los intereses generales y enterados de su relevancia- la recta razón y el buen sentido tildan la posición contraria de antisocial y reñida con la naturaleza de las cosas. Una lectura comprensiva y no taimada del art. 53.2 CE permite asegurar que, preservadas la garantía de la reserva de ley y la prohibición de vulnerar el contenido esencial, el desarrollo legislativo de los derechos innatos que lo demandan concretando la hondura y la extensión de su tutela-forma parte de sus requerimientos intangibles. Ello hace falta para proteger las preferencias y valores que ocupan el núcleo invulnerable y sus espacios periféricos. El reto de la cláusula transformadora y social del art. 9.2 CE compromete a los poderes 
públicos $\mathrm{y}$, aludiendo a la parte del todo que les corresponde, recuerda las obligaciones naturales -inscritas en el marco del decisionismo político y no, por ello, menos perentorias- que, unas veces, proceden de genialidades creadoras y, otras, pertenecen a enunciados parciales, como el del art. 53.3 CE. El art. 9.2 CE se apropia la especificación que, conforme al rigor y la emocionalidad de su mensaje, transmite a los poderes públicos - entre los que figura el Poder Legislativo- la tarea de definir y ejecutar las cargas que, reforzando la libertad y la igualdad de los individuos y grupos intermedios, dibujan una sociedad caracterizada por el celo con que se entrega a confirmar las premoniciones del espíritu de cambio. La sujeción de los poderes públicos al ordenamiento jurídico no se ciñe a los mínimos de sometimiento que dictan las moderaciones usuales del ejercicio del poder. Comprenden modelos de actitudes atípicas que, en permanente ebullición, resaltan la emergencia de los derechos innatos y ofrecen -quemando, a veces, las etapas en que se desaceleran sus ritmos- fórmulas aptas para restaurar su bagaje de modernidad.

El hecho de que la igualdad y la libertad -a reserva de que, en su caso, dejen de emparejarse y prevalezca una sobre otra- compartan la pretensión de devenir fogosamente reales y efectivas, abona reflexiones pródigas en ingenio y ambiciones morales. Para escapar de sus secuestradores, la libertad ha de impregnar cuantas realidades acrediten -dentro de una comunidad identificada con ella- el protagonismo de las personas físicas y de los grupos que, poblándola en un régimen de conflictividad normalizada y aceptable, esculpen el rostro -verdadero y no desfigurado- de la sociedad pluralista. La libertad deja de serlo, sin perjuicio de sus restricciones naturales, cuantas veces se oculta o disimula su cualidad central. A saber, la explicación o clave de por qué la persona no debe seguir siendo, como sostuvo el existencialismo pesimista, un ser sin guía, que, una vez arrojado a las turbulencias de este mundo, queda desorientado, indefenso y expuesto a la infinidad de los vaivenes y agresiones que le toca sufrir en el reparto de los males. Víctima del oprobio con que la crueldad de la Historia cotidiana le hostiga y trunca las oportunidades de amparar -erguida y animosamente- su dignidad puesta en entredicho. Es decir, de erigirse en la razón de ser de una concepción antropocéntrica, de la de quienes la asumen en sus espacios habitables y de la conexión equitativa de su voluntad - celosa defensora de un acervo de funciones sociales - con los que supeditan su suerte al triunfo de estas iniciativas y enriquecen los intereses generales con los réditos de su prosperidad. He ahí el sentido ordenado de los cosmodesignios que, si se atienen a su norte moral, justifican las planificaciones debidas al progreso de las voluntades -individuales y colectivas- que cumplen las consignas básicas de un orden natural cuyo peso específico obliga a estar al tanto de la evolución o la revolución de sus contenidos variables. Máxime, si las interacciones traslucen unas realidades propensas al calor de la reciprocidad que se promueve e indignas de las perversiones que las entumecen. 
La igualdad -conducente a conclusiones análogas- mora en zonas o pasajes históricos que requieren un enérgico apoyo de presente para que sus buscadores cobren los créditos de la necesidad liberadora que es el título de su reclamación. Exige restricciones -de carácter didáctico y social-para que cuantos la propagan, con demagógicos halagos y torpeza simplificadora, sepan de los esfuerzos dirigidos a reponer su calidad de origen y no enturbiarla con sofismas y lugares comunes. La selección y el reparto de las vías de acceso a la atribución de los derechos innatos, crean las oportunidades de que, ejercitando el derecho de acción procesal, sus titulares puedan alzarse en pie de guerra. Acuden, unas veces, a la efectiva tutela judicial que ofrece el novedoso art. 24.1 CE para disuadir de la tentación de autojusticia. También apelan a formas de presión extrajudicial institucionalizada, como la que, diferenciando la titularidad individual y el ejercicio colectivo del derecho de huelga, reconoce el art. 28.2 CE, que ha elevado a la segunda potencia -giro muy caro a los pioneros del Derecho Procesalla cobertura de unas libertades sindicales que ensalzan las virtudes de la desigualación igualitaria.

Abierto a las expectativas de omnicomprensión con que el art. 53.1 CE se hace audible, el ordenamiento jurídico acrecienta la fuerza expansiva de los derechos innatos y anuncia la voluntad de perpetuarlos para que su plenitud atestigüe la proliferación y la efectividad que les incumben. El dogma de su contenido variable hace saber que su existencia -adaptada al peso de los acontecimientos influyentes y a la credibilidad de las demandas socialesse atiene a un criterio doctrinal de continuidad y a una regla histórica de progreso. El que haya contenidos variables constitucionalmente confiados a la regulación parlamentaria de los derechos innatos, no impide que el decisionismo político repare en otros derechos -asímismo cuasinaturales- sobre cuya expansión el constituyente nada dice. No es necesario invocar la precedencia de un imperativo constitucional soterrado o implícito, allí donde, aun a falta de este encarecimiento, la autonomía del legislador le aconseja de acuerdo con las insinuaciones de su decisionismo. No hay que apelar, encogiendo el brazo, a un encargo constitucional de legislar, si -ponderando los elementos personales, temporales y reales- la esencia del decisionismo incluye las responsabilidades anejas a requerimientos que, so pena de postergar los intereses generales, el legislador no puede desoír. El empleo del modo subjuntivo del verbo «regular» en el art. 28.2 CE -donde la regulación y la autorregulación de la huelga son igualmente constitucionales-sugiere un análisis conexo con las consideraciones anteriores.

Existe algún ejemplo de interpretación voluntarista de la legalidad fundamental, llamada así porque la invocación del pluralismo político no autoriza a encontrar un imperativo constitucional allí donde el constituyente sólo hace mérito de una posibilidad que no conmina de inmediato y queda al albedrío de la prudencia y la ponderación legislativas. Se rotula de mandato inaplazable alguna sugerencia que el legislador ordinario puede atender, por 
propia autoridad, en el ejercicio de sus prerrogativas. La participación popular en la Administración de Justicia, por citar un ejemplo, no emana de una inclemente exigencia constitucional, sino de una elección que el art. $125 \mathrm{CE}$ elogia o aconseja, pero nunca impone. La implantación del Jurado demuestra los reparos o fracasos de atribuir al constituyente una intención que, en vez de acomodarse al posibilismo de las realidades sociales, se ofreció como una panacea que no ha cosechado un éxito aplastante.

Otro tanto sucede con las proclamaciones o principios de corte programático que, aludidos en el art. 53.3 CE y a la espera de su desarrollo legislativo, no ingresan en el ámbito del Derecho constituido que reconoce el derecho procesal de acción -integrador de los derechos fundamentales de tutela judicial efectiva y de acceso a la jurisdicción- para salvaguardar su contenido esencial y sus extensiones periféricas. Resulta inexcusable un desarrollo exigido por el principio de responsabilidad de los poderes públicos, del que -si el art. 9.2 CE se lee sin prejuicios reductores- no pueden hacer los legisladores caso omiso. Decayeron las afirmaciones de que el trabajo de éstos era irreprochable, cuando hoy no escapa al control de los juicios de constitucionalidad, de que las acciones del Gobierno y la Administración eran irresistibles, cuando hoy se cuenta con recursos jurídicos hábiles para frenar sus demasías, y de que la jurisdicción era irreprehensible, cuando su sistema actual de impugnaciones se funda en la falibilidad humana y en la ¿confianza? de la opinión pública en la Administración de Justicia. Se deduce así de los arts. 117.3 y 4, 122.1 y 123.1 CE. Los poderes públicos del Estado social y democrático de Derecho se sujetan a la alternativa de que sus decisiones se reformen, si ha lugar a impugnarlas, o de que, cargadas de razón, prevalezcan sobre el recelo de aquellos cuyos intereses no logren la protección solicitada.

El constituyente no ha dotado al legislador de un cheque en blanco para cumplir esos deberes de desarrollo y ampliación, cuando su razonable arbitrio le indique que ha llegado el momento de hacerlo. La predicción de responsabilidad le somete a una limitación que, además de yacer en la naturaleza de las cosas y derivar de las relaciones éticojurídicas, figura en algunos pasajes del Derecho Positivo, como el art. 1.128 I C.c. Esta regla -corolario de la que, al evocar la buena fe, establece el art. 7.1 C.c. sobre el ejercicio regular de los derechos y la ejecución tempestiva de las obligaciones- recuerda que, si una obligación no fija plazo para realizar las prestaciones que constituyen su objeto, pero de su carácter y peculiaridades se deduce que ha querido concederse al deudor, se otorgará un período equitativo de tiempo para efectuar el preceptivo cumplimiento. Interviene un mecanismo integrador que -al defender al portador del interés afectado- decide sobre la extinción de un compromiso que no puede quedar, en cuanto al si, al arbitrio del deudor, ni depender, tocante al cuándo, de una duración indefinida. 
La inacción que -al cabo de más tiempo que el recomendable por la recta razón y el buen sentido- comete el legislador que, pudiendo y debiendo legislar, se abstiene de hacerlo, tiene que acarrear una sanción peculiar, si se quiere, pero insustituible en defensa de los intereses generales de la ciudadanía confiada en la coherencia y la lógica del ordenamiento jurídico. El principio de igualdad ante la ley se infringe si subsisten zonas insulares de ciudadanos privados del acceso a las normas de desarrollo que la legislación ordinaria les deniega o aplaza injustificadamente. El Poder Judicial cumple las funciones de suplencia que -sirviéndose, a veces, de instrumentos mellados- asume en homenaje a la invitación del art. 9.2 CE, al hacer efectivas la sanción de esas omisiones y, si ello cabe, de la incursión en responsabilidad legislativa. Lo ratifica el art. 5.1 LOPJ, que -vigente ya el cuerpo de la legalidad fundamental- quiere borrar la distinción -académicamente apreciable - entre sus normas vinculantes y las que no lo son. El legislador ordinario -castigándose a si mismo, como el protagonista de un conocido drama de la antigüedad clásica- comprende y acepta que, si el tiempo transcurre estérilmente a la espera de la contribución legislativa, el Poder Judicial tiene que reaccionar como un legislador ocasional que suple esos atrasos. De ahí no pasa la sanción imperfecta que -en punto a dicha responsabilidad y mientras no medien dispositivos más enérgicosdeterminan la mora legislativa o la omisión de las conductas que, adeudadas por el legislador ordinario, caracterizan a un comportamiento diligente. Actitud que, si conceptualmente no rebaja la plenitud del ordenamiento jurídico, desacredita a los encargados de poblar -con las normas del Derecho constituido- el espacio habitable por la expansión del imperio de la ley. Ha de evitarse el daño atribuido a la ausencia de una regulación conveniente a sus destinatarios, que, aunque sujetos al ordenamiento jurídico por el art. 9.1 CE, son portadores de un interés directo en aprovechar las mejoras de la seguridad jurídica material. No han de sufrir para siempre los inconvenientes -reductores de esa seguridad- de un exceso de llamamientos a las fuentes secundarias o a las reglas integradoras del Derecho objetivo. Estas huelgan si, antes de manejarse la analogía y el Derecho supletorio citados en el art. 4.1 y 3 C.c., no se descartan minuciosamente las opciones de aplicación directa de la norma o normas con las que se trabaja.

El razonamiento se predica del desarrollo legislativo de los derechos innatos - dotados de eficacia preceptiva directa y necesitados de actualización- y del pormenor de los principios que, mientras no incorporen las amplificaciones y refrendos que un legislador escrupuloso debe introducir, no cuentan con el derecho procesal de acción para obtener los bienes jurídicos apetecidos. Así lo da a entender el art. 53.3 CE. La garantía, adelantada por el constituyente, es eco del mensaje transformador del art. 9.2 CE, de cuya promesa liberatoria los principios rectores de la Política Social y Economica ofrecen una selección inicial a la que, andando el tiempo, han de agregarse las oportunas decisiones del legislador ordinario. 


\section{GARANTÍA DE LA INDEMNIDAD FUNDADA EN EL DESARRO- LLO DE EXIGENCIAS CONSTITUCIONALES IMPLIICITAS}

Otro elemento estimulante de las acciones de refuerzo de la plenitud del ordenamiento jurídico, no emana de una exigencia constitucional específica y sí del diagnóstico de las situaciones de interés general-visión secular del bien común aristotélicotomista- que, a medida de su hallazgo e identificación, se incorporan al elenco de los intereses desnudos. Desprotegidos por el Derecho objetivo, palpitan en los ámbitos donde se adivina y difunde lo provechoso de tenerlos en cuenta. Los intereses desnudos devienen intereses vestidos desde que el legislador les asigna el carácter de derechos subjetivos o situaciones jurídicas que confieren el derecho fundamental a que -ante un episodio conflictivo- los órganos jurisdiccionales competentes dispongan de criterios bastantes para que el discurso - verificado y persuasivo- del Derecho permita resolver, sin interposiciones rituales obstaculizadoras, las cuestiones de fondo. La selección de los intereses generales, cuya mejora se propone, depende de la razonabilidad del albedrío y de las sensibilidades ideológicas que -a través de sus dosis de implantación o representatividad parlamentaria- el grupo legitimado para ello transfiere al ordenamiento jurídico. También atañe a la elasticidad -confundida, a veces, con la laxitud-de que, sin contrariar la letra y/o el espíritu constitucionales, la legislación hace gala cuando se adueña de los espacios -desdibujados y extensos hasta entoncesdonde sus inquietudes quieren acampar. Debe ejercitar - poniéndola a prueba concienzudamente- la celeridad del diagnóstico de los intereses generales y acreditar su acierto mediante iniciativas responsables y no condescendientes con la versatilidad de los voluntarismos rupturistas. Aprecia cómo y cuándo la Política Legislativa ocupa decorosamente su espacio habitable -moviéndose con soltura en su interior- para rehuir los efectos desproporcionados o menguar las desigualdades preexistentes. El legislador ha de captar -con devoción y conocimiento de causa- los estados de cosas relevantes de la moralidad política y la cordura de su actividad discrecional. La postura voluntarista o radical -lo bueno es tal porque quien manda así lo quiere y estable$c e-$ del decisionismo político, cuyas versiones abusivas adquieren temibles resonancias, puede patrocinar soluciones que, ante el apasionamiento numeral de las mayorías parlamentarias que les son afectas, producen -en vez de un raciocinio saludable y pausado- debates destemplados y poco edificantes. Ofrecen, a menudo, la traza y los afanes de un paseo militar parlamentario al que no es fácil oponer una resistencia compacta, pese al énfasis con que el art. 128.1 CE prescribe la subordinación de las formas y la titularidad de la riqueza al servicio de los intereses generales del país.

El manejo abusivo del concepto de interés general no siempre se advierte con infalible transparencia. Hay que determinar si las querencias tendenciosas se apartan de la homogeneidad de las demandas sociales y eluden los criterios de una opinión pública verazmente informada para diseminar sus preferencias y denunciar los actos que las entorpecen. Los controles de 
un juicio de constitucionalidad resuelven poco o nada en un sistema donde la superioridad del pluralismo político - variante de la libertad que, sumada a la igualdad, completa la omnicomprensión de la justicia-permite artificios de ingeniería maleables e inmunes a la fiscalización de sus componentes de interés general, dadas la naturalidad y la frecuencia con que se exaltan o pasan a segundo término. Son salidas que, aunque emergen en los límites de la prestidigitación y no coinciden con otras opciones políticas minoritarias, tampoco atentan frontalmente contra los principios y preceptos de la carta política. Surgen en circunstancias que inducen a esas anomalías y que, sin violar la legalidad fundamental, se asemejan a un abuso deshonesto de lo que son y significan sus pautas. Transigir con estos pecados veniales -que, a veces, rozan con conductas de gravedad probada, aunque respeten la distancia imperceptible que les inmuniza- es el precio político puesto a la recepción del consenso que aporta una nueva herramienta de trabajo a la factura del proceso constituyente. La sociedad -que, por una u otra razón, no reclamó esos bienes- sufre el castigo de las decisiones unilaterales que, invocando la voluntad política, registra el mercado de los intereses no generales en las zonas inconsistentes o difusas del tejido social. Se echa de menos una atención homogénea de las demandas sociales sustituidas o, si hay grave olvido de los intereses afectados, suplantadas por mensajes huérfanos del mínimo de fidelidad al bien común que la lealtad política prescribe. O bien se emprende la busca de las auténticas demandas sociales y se comprueba la insuficiencia denunciada -que el legislador debe subsanar con prudente discrecionalidado bien se analizan las demandas sociales cognoscibles para esclarecer lo que de hay en ellas de excitación engañosa o populismo cegador. La regla vale para las ofertas politicas cursadas a sus destinatarios y al resto de las opinión pública. Ceder ante reivindicaciones que, a pesar de sus orígenes espurios, se dicen auténticas demandas sociales, equivale -si el legislador las digiere de modo automático y no separa la paja del trigo- a triturar los valores de la generalidad de la ley. La libertad del decisionismo político se ha pensado para seleccionar y proteger los intereses atendidos bajo condiciones más o menos explícitas, pero acercándose, con ambición moral, a los requerimientos de sus funciones sociales y a las ventajas que la sociedad pluralista deduce de estas experiencias. La magnitud y variedad de los frentes que la desafían -ante los que ha de definirse o aplazar su respuesta para mejor momento- explican la mediación de los legisladores en el tratamiento complementario de las libertades y derechos innatos que dependen de esas iniciativas.

La indemnidad preventiva responde a la celeridad con que el ordenamiento jurídico adquiere plenitud y ocupa -para servirlos generosamentelos reductos de la vida de relación, prefiriendo a los que sufren una existencia frágil o sienten más agostados sus destinos. Esta indemnidad afianza la solidez y el crecimiento de las relaciones tejidas en el seno de la sociedad general -organizada en el Estado social y democrático de Derecho-y de las sociedades parciales que se integran en ella satisfactoriamente. Relaciones 
impregnadas del bienestar que -al desencadenar deseos o apetencias- refleja el elemento intelectual de la materialidad económica o del interés tangible que explica la defensa de la indemnidad con cargo al valor superior del pluralismo político.

\section{TUTELA DE LA DIGNIDAD CON CARGO AL VALOR SUPE- RIOR DEL PLURALISMO POLÍTICO}

$\mathrm{El}$ art. 1.1 CE contiene un elemento de indemnidad relativo al componente ideológico de las actitudes individuales y de los comportamientos políticos. La preocupación -legítima y útil- por ultimar este detalle, proviene de la lista de los valores superiores del ordenamiento jurídico que, planteando un reparo de arte menor o secundario, descubre, quizás para fijar fuera de duda sus orígenes, la desproporción métodológica del interior de su enunciado. Son valores simultáneamente superiores al resto del ordenamiento jurídico e interiores a la figura piramidal elegida para representarle. La tradición geométrica de diseño del ordenamiento jurídico se serviría mejor si, en vez de la pirámide, se imaginase un cilindro fragmentado en tantas divisiones como sectores de aquél fuesen reconocibles y vigentes. El art. 1.1 CE altera el usual paradigma normativo -refundición de los yusnaturalismos polémicos- y traslada sus predilecciones a un solo valor - primordial y prevalentedel que los demás que se enuncian son experimentos o derivaciones. Una de éstas contempla la indemnidad de las opciones ideológicas en sus versiones tradicionales o recientes. Inmunes, unas y otras, a cualquier amenaza de marginación o achicamiento. Tal es la clave del acceso a un panorama general de indemnidad para el pensamiento y las acciones derivadas del mismo. ¿Por qué ha de suceder así?

La irregularidad de método -enunciativo y sistemático- se advierte la luz de la relación entre el art. 1.1 CE - pieza capital y objeto de interpretación- y la consigna de transformación estampada en el art. 9.2 CE. Se reiteran las partes de un todo -cuyo enunciado era bastante- y, además, se menciona el pluralismo político como aspecto de aquéllas. El examen del art. 1.1 CE requiere precisar si fija pulcramente una pluralidad de valores superiores del ordenamiento jurídico o si, con laxitud métodológica, añade al género o al todo las especies o partes integrantes y aun los corolarios o accesorios de algunas de estas últimas. Parece que ha ocurrido así y que no huelga una relectura de aquel texto. La concepción aristotélicotomista de lo que la justicia es y significa, sostiene que el conjunto de sus excelencias colma las condiciones de la dignidad individual a medida que lo reclama el modo que -sin servidumbres ni entorpecimientos excesivos- la persona física tiene de comparecer en el mundo y deambular por sus compartimentos. Es la contrafigura del señuelo del fin de la historia que -menoscabando las esencias de la libertad y la igualdad-predijo, como conquista irrenunciable, la imagen de una sociedad en la que cada uno contribuiría según sus posibilidades, por módica que fuese su disposición cooperativa, y recibiría según 
sus necesidades, si, pese a la modestia de esa contribución, frecuentaba las querencias más voraces de su voluntad de disfrute.

La dignidad satisfecha coloca a las personas en estados individuales o colectivos de justicia, si los sujetos que aspiran a plenificarla no sufren diferencias de trato arbitrarias, ayunas de justificación objetiva y razonable, ni se lastiman sus propósitos de aprovechar la igualdad para realizarse hasta donde lo permitan sus disponibilidades y su inventario de ilusiones. El acto de presencia del art. 9.2. CE -criterio contextual y sistemático de interpretación en el seno privilegiado del TPCE (Título Preliminar de la Constitución española de 27 de diciembre de 1978)- enseña que la conjunción armónica de las libertades e igualdades reales y efectivas afluye a una síntesis en la que prevalece el supremo valor de la justicia. Referirse-como, en pie de paridad conceptual, hace el art. 1.1 CE- a la libertad, la justicia y la igualdad-es mezclar el género -la justicia-con las especies de la libertad y la igualdad. Una recomposición más atinada del art. 1.1 CE podría rezar: El Estado social $y$ democrático de Derecho, en que España se ha constituido, propugna, como valor supremo y omnicomprensivo de su ordenamiento jurídico, la justicia material que armoniza y condensa la libertad y la igualdad. Así queda emplazado el único y supremo valor -en vez de tres, ya que dos de los mismos se subsumen en él- del ordenamiento jurídico.

El pluralismo político es otra facultad o, si se prefiere, irradiación del bien central de la justicia, porque, sumado a los más caros testimonios de la libertad, intensifica la aspiración a una igualdad copiosa en las experiencias propias de su fisonomía. El pluralismo político emana de la igualdad -integrante, no huelga repetirlo, del supremo valor de la justicia- porque se vedan las discriminaciones que, menoscabando la existencia de las personas y los grupos sociales, coartan la finalidad y el ejercicio de las libertades en cuanto a sus preferencias ideológicas generales, sociales, religiosas, económicas, lúdicas y cuantas otras traen causa de su autorregulación o autonomía. Vuelven éstos a ser elementos contextuales de interpretación que desbaratan los obstáculos opuestos a las proclamaciones de igualdad formal y a los esfuerzos de su endurecimiento. El pluralismo político pertenece a la evidencia de las libertades, pues, conforme a su significado etimológico, el art. 1.1 CE ensalza la receptividad que le distingue y la pulcritud con que han de analizarse las modalidades de legislación material o vertical que sus opciones den a conocer. No hay necesidad de acometer la reforma constitucional prevista en el tít. X CE para que cualquiera de esas expresiones quepa en las ofertas de sus portadores naturales- los partidos políticos que, según el art. $6 \mathrm{CE}$, ostentan dicha condición- o de los grupos vertebradores intermedios que, como reza el art. 9.2 CE, acogen a los individuos colectivamente asentados en sus cuerpos y almas. Ello acontece en el seno de la sociedad a cuyo pluralismo alude, de pasada, el art. 20.1 CE, admitiendo que soluciones legislativas incompatibles o antagónicas pueden, no obstante, preservar su fidelidad a la letra y el espíritu constitucionales. El respaldo poliédrico del pluralismo político 
tolera una diversidad de lecturas plausibles de los preceptos constitucionales objeto de análisis. Otro tanto se afirma, guardadas las distancias, de la aprehensión y formulación de los principios constitucionales que brotan de un entendimiento liberal gobernado por el ingenio de sus descubridores.

\section{GARANTÍA DE LA INDEMNIDAD FUNDADA EN LA PRESUN- CIÓN DE JUSTICIA MATERIAL Y NO SÓLO DE LA ESTRICTA VALIDEZ DEL ORDENAMIENTO JURÍDICO}

Del art. 1.1 CE arranca una enérgica presunción inicial que es parte de un pasaje -a saber, el TPCE- donde las predicciones axiológicas, prestas a incorporar y difundir un bloque de moralidad legalizada, se abren paso frente a los paradigmas del normativismo que explicaban el progreso del Derecho a través del equilibrio inestable- pero equilibrio, al fin y al caboque garantizaban sus normas. Superadas las vacilaciones del yusnaturalismo evanescente, cundió la idea -intelectualmente pacífica y socialmente pacificadora- de que el ordenamiento jurídico emprendía un ascenso en busca de la norma suprema que cerraba la figura piramidal elegida para representarle. Valga decir, una vez más, que la imagen geométrica conviene exactamente a la de un sólido cilíndrico repartido en los sectores integrantes de las parcelas del Derecho Público y el Derecho Privado que agotan esa división. La inconmovilidad del ordenamiento jurídico nacía de la voluntad del titular de la soberanía, cuyas eran las iniciativas de esa elaboración y postura. Se justificaba porque, si el texto constitucional -fruto de una decisión fundamental- no garantizaba el equilibrio y la coherencia del sistema positivo de normas, el ordenamiento jurídico se desplomaría y sus elementos emprenderían una retirada cabizbaja, anárquica y ostensiblemente vergonzosa. La contextura del TPCE prueba que la sensibilidad y la elasticidad éticas vencen, si se lo proponen, a las servidumbres del normativismo a ultranza. De ahí, que, para no fracasar en el vacío, se eche mano del impulso binario que abarca la exaltación de la justicia a cargo del art. 1.1 CE- como supremo valor del ordenamiento jurídico-y las ventajas de la cláusula transformadora y social que, purgada de sus radicalismos, el art. 9.2 CE ha importado del art. 3 II CI (Constitución italiana de 27 de diciembre de 1.947). Estas innovaciones mudan el centro de gravedad de los pasajes privilegiados del TPCE, hasta el punto de que, volviendo a lo ya dicho, la proposición ordenada y cabal del art. 1.1 CE puede reformularse así: España se erige y constituye en un Estado social y democrático de Derecho, que, como supremo valor de su ordenamiento jurídico, reconoce la justicia material que, aposentada en su interior, sintetiza la igualdad y la libertad efectivas, cuyos objetivos de transformación y de cambio no se alcanzan sin la asistencia del pluralismo político.

La exégesis del art. 1.1 CE no se detiene aquí, a falta de otras reflexiones axiológicas sobre el relieve que el constituyente atribuye al supremo valor de la justicia como compendio de todo su enunciado. La apuesta por la preponderancia de lo justo no se limita a presumir que -según un optimista entendi- 
miento- la impecabilidad de la carta política se debe a que el supremo valor superior de la justicia enfervoriza los mensajes de sus principios y preceptos. Algo de ello se relacionaría con un tácito afán compensatorio, consecuente con los pareceres a que dio lugar alguna incidencia técnicojurídica de la transición democrática. Hubo pensadores que, cautivos de su purismo intelectual, subrayaron la singularidad histórica del proceso constituyente y censuraron sus heterodoxias. Sostuvieron -con argumentos persuasivos y audibles- que ese proceso no reunía las condiciones requeridas por su perfección jurídicopolítica. No se reconocían ni salían a la superficie la claridad y la continuidad del ciclo por el que el pueblo -titular originario o en raíz de la soberanía- se desprendía, temporal y voluntariamente, del poder político y lo transfería al nuevo titular provisional del poder constituyente. Poder temporal, no como herramienta del mundo secular y opuesto a los poderes espirituales, sino comprensivo de las operaciones - concatenadas hábilmente- de factura de la carta política. El ejercicio del poder constituyente troquelaría el texto constitucional, agotaría la delegación venida del pueblo soberano y dotaría de un sistema de poderes constituidos que refrendaría el titular originario. El poder constituyente no podía emanar, así las cosas, del pueblo atenazado por un régimen paternalista autoritario, sucedido por el proyecto del Estado social de Derecho que auguraba la marcha compartida hacia el ifin feliz? de la transición democrática. La delación de un poder constituyente regular no encajaba en los moldes de esa morfología y transmisión, aunque, para templar la insuficiencia, se haya apuntado la figura de un poder constituyente evolutivo que haría sus veces en tan excepcionales circunstancias.

Medió, como era de esperar en ese trance, la novedad del uso alternativo del Derecho que - bajo la enigmática premisa que rezaba «de la ley a la ley y- forjó la LRP (Ley de Reforma Política de 3 de enero de 1976) y disfrazó nominalmente, tildándole de cambio cuasisustancial, el que -llamando a las cosas por su nombre, pues no se vislumbraba otra salida- era un desmantelamiento de las instituciones o ruptura de fondo con el cuerpo y el alma del paternalismo autoritario. Esta objeción -flotante en el centro y en la periferia del hecho constitucional puesto en marcha- revivía la burlesca imagen del rey desnudo y halagado por los cortesanos que servilmente elogiaban la donosura de su vestimenta inexistente. La presunción general de justicia - predicada de los principios y preceptos constitucionales-y el enclave de la justicia material en la cúspide del ordenamiento jurídico, sirvieron al criterio de que un defecto insubsanable -como la formación anómala del poder constituyente- se compensase con los merecimientos del esfuerzo desplegado para asignar a esos principios y preceptos el óptimo y el máximo de justicia material que, en cada caso, toleraban las movedizas circunstancias de su puesta en escena. La afirmación terminante del art. 1.1 CE -en pro de esa opinión- supliría la cortedad del poder constituyente que se ha censurado. 
Adjudicar a la justicia -continente de los elementos y subespecies que enumera el art. 1.1 CE- el carácter de supremo valor del ordenamiento jurídico, exige un emplazamiento convincente. Si se admite que la legalidad fundamental culmina la figura piramidal de dicho ordenamiento y se insiste en la presunción general de justicia de sus contenidos, solamente se acepta que el óptimo de la justicia perceptible -elemento capital de control- reside en los principios expresos o tácitos y en los mandatos y/o prohibiciones de la norma fundamental del Estado. El art. 1.1 CE cobra una significación declarativa que, emparentada con las intenciones del Pr.(Preámbulo) CE, complementa ese proemio con las diferencias dogmáticas e históricas -de todos conocidas- que implican sus paternidades y que tampoco hay que exagerar en perjuicio de la coherencia interpretativa. Curioso maridaje, el que se aprecia entre la introducción y el pasaje inicial privilegiado de la carta política. El esfuerzo transformador - propagado por el art. 9.2 CE a la letra y el espíritu de los preceptos que se le aproximan- invita a ensayar, voluntariosa y audazmente, cuantas interpretaciones animan la localización del espíritu móvil -ingeniosa ocurrencia de los canonistas medioevalesque invita a sumergirse en las vicisitudes del cambio y a aclarar la seducción de sus propósitos. La conclusión es contundente en pro de la celeridad y calidad de las mudanzas deseables. Los pasajes constitucionales reclaman pautas de interpretación más numerosas y distintas de las del art. 3.1 C.c., que, pese a su naturaleza cuasiconstitucional, no se ha pensado para interpretar la carta política, aunque suministra las referencias hermeneúticas que lo hacen factible. Atenerse al sentido propio de las palabras de la norma jurídica supone un criterio al que se acude para entender el significado de la contracción gramatical «del»-que refundiendo la preposición «de» $\mathrm{y}$ el artículo determinado «el»- precede al sustantivo «ordenamiento». Dicha contracción designa una relación de pertenencia, no de simple contigüidad o cercanía, y enseña que el supremo valor de la justicia reside en el interior de un ordenamiento jurídico que cobra un dinamismo más valioso que él derivado de situar la carta política fuera de su composición piramidal. De acuerdo con la pertenencia que pone en su lugar al supremo valor de la justicia, ésta opera dentro y no extramuros del ordenamiento jurídico. Según la preeminencia que así adquiere, el supremo valor de la justicia -amén de esa interioridad- prevalece sobre la ley fundamental. Puede alegarse y aplicarse para concluir si el constituyente ha incumplido los compromisos contraídos con su preponderancia y jerarquía. Si, en función de este razonamiento, se examina la dicción del art. 1.1 CE, la estructura del ordenamiento jurídico englobaría el cuerpo intermedio constitucional o carta política escrita, el resto supraconstitucional que, antepuesto jerárquicamente, remoza y aporta los contenidos variables del supremo valor de la justicia, y el resto subconstitucional comprensivo de la legislación material o vertical, las costumbres y los principios que atienden a la plenitud del sistema de fuentes del Derecho objetivo. Se supera la idea de que el valor superior de 
la justicia sólo es una realidad menos tangible que impregna, desde fuera, la porosidad de un Derecho constituido con el que se muestra simplemente comunicativa, cuando, en verdad, forma parte de un ordenamiento jurídico que, sin su inclusión, queda mutilado y deja de ser íntegro. La justicia material controla sus vicisitudes a la luz de los postulados que -atemperados a los signos de los tiempos- actualizan los contenidos variables del orden natural y de su bloque de moralidad legalizada.

De lo expuesto se sigue que la constitucionalidad impecable y completa de una norma jurídica requiere analizar su adecuación al supremo valor de la justicia y, si hay conformidad, contrastarla con los principios y preceptos constitucionales a que su validez se subordina. Este planteamiento de axiología binaria no es el frecuentado por los juicios de constitucionalidad, que no parten de la jerarquía que se ha defendido ni han abordado la cuestión -que tener precedentes, los tiene- de la nulidad de las normas constitucionales o de los desarrollos legislativos que infringen el supremo valor de la justicia. Amén de compartir la postura templada y general que atribuye al texto constitucional el carácter de norma suprema del ordenamiento jurídico, el art. 5.1 LOPJ -que no tanto pretende adoctrinar sobre el entendimiento de las normas constitucionales, cuanto dilucidar su enclave en el sistema de las fuentes del Derecho objetivo que aplican los jueces ordinarios- mantiene una actitud ecléctica de proporciones medias.

No está de más completar la reflexión sobre dos versiones -doméstica la una y cuasiyusnaturalista la otra- del papel que cumple el supremo valor de la justicia material. Se trata de la declaración que, incluyéndola en el elenco de los valores enunciados, emite el art. 1.1 CE sobre la función y utilidad del pluralismo político. La alusión presenta un alcance deontológico y fáctico. El primero de ellos se extrae, sin mayor dificultad, del análisis general que acaba de hacerse. El segundo es típico de las normas jurídicas de comprobación que, además de ofrecer los contenidos normativos que reparten, habilitan, mandan o prohiben, ceden a la tentación de glosar-algo crípticamente- el hecho histórico de su estreno. La mención del pluralismo político elogia la acción representativa de los partidos -que, como promotores de origen, enfatizan sus preferencias ideológicas-y de su práctica por grupos innominados que, sin esa legitimación directa, intervienen como sus portadores sociales. La correlación de los arts. 1.1, 6 y 9.2 CE permite sostenerlo así. El aval del pluralismo político - que, como norma de constancia, incorpora el art. 1.1 CE- es la ¿aceptación confiada y optimista? de que -superados los antagonismos entre la rigidez de la esencial enemistad y la ductilidad del pluralismo social- se disponga de un ¿edificio habitable? donde -si, en verdad, lo quieren los invitados a cincelar un porvenir armónico y fecundo- se traigan a capítulo los proyectos meritorios e imaginativos. La abundancia de conceptos jurídicos indeterminados del texto constitucional autoriza lecturas acordes con ideologías divergentes, cuya incompatibilidad colocaría a unos u otros al margen de la legitimidad cons- 
tituyente. Trazaría una línea maniquea de separación entre los respectivos pensamientos, si el papel salvífico del pluralismo político no corrigiese los inconvenientes de esa envergadura.

\section{6. ¿CONSTITUCIONALIDAD O CONSTITUCIONALIZACIÓN DEL USO ALTERNATIVO DEL DERECHO?}

El uso alternativo del Derecho fue un remedio ideado -tras las frustraciones que forzaron la intrepidez de sus apariciones- para liquidar la contumacia del legislador ordinario que -haciendo caso omiso de su trascendencia- prescindía de la elogiable orientación del art. 3 II CI. Este precepto -de fatigosa introducción en algún texto de la legalidad fundamental contemporánea- depositaba su confianza, gracias a las perspectivas de cambio, en la imaginación y la rapidez de las acciones de la legislación ordinaria postconstitucional. Operaciones de mudanza social que - puesta la vista en un futuro regenerador y cercano- impregnaban los términos de su formulación. Pendía el problema de rehabilitar los valores de la cultura judeocristiana que, tras un prolongado eclipse, revivían a raíz del reparto ideológico de una Europa dividida en áreas de influencia y zonas de sometimiento. El art. 3 II CI aportaba la idea -cuyo enlace con el pensamiento jurídico soviético no mermaba el aliciente de su recepción- de que el Derecho constituido no sólo estaba ahi para resolver los conflictos surgidos entre las personas físicas y/o los grupos en que se insertaban. También le apremiaba la carga de transformar la sociedad organizada en el Estado democrático según los términos de una revolución venida de lo alto. La promesa del constituyente postbélico vivificaba un compromiso de cuyo cumplimiento dependía la consolidación de los bienes jurídicos adeudados a los grupos indigentes de una sociedad confiada en el triunfo de sus más justificados anhelos. La incidencia numeral de las mayorías políticas en la producción legislativa determinó que, a la larga, el impacto del art. 3 II CI se degradase a un espejo -desteñido y opaco- que el legislador arrinconaba y en el que desistía de mirarse para no confesar sus frustraciones. El art. 3 II CI devino una norma petrificada y platónica, despojada de valor vital e invocada, sin éxito, al calor de unas realidades sociales que, aguardando su turno por tiempo indefinido, se disolvían a causa de su marginación. Desafiada por la desmemoria de los legisladores ordinarios que pasaban de largo ante la legítima impaciencia revolucionaria del esfuerzo de transformación.

El uso alternativo del Derecho -sucedáneo de un pluralismo político que aquellos legisladores no habían refrendado- incidía en un Derecho Positivo huérfano, hasta entonces, de las enmiendas peculiares del signo de los tiempos. Sus defectos se reconstituyeron mediante reflexiones rupturistas que, advirtiendo y alegando los escollos de sus episodios judiciales, moderaron y/o eludieron las dificultades que aquejaban al ejercicio jurisdiccional. El uso alternativo del Derecho defendía -como solución minimalista- el recurso a los elementos de interpretación evolutiva apuntados en el art. 3 II 
CI y -como elección maximalista- las opciones de ruptura fundadas en la supremacía jerárquica de las normas constitucionales sobre una legislación plagada de olvidos y lagunas. La rigidez de una interpretación conforme a la voluntad del legislador predemocrático y la resistencia a las propuestas de adecuar las normas jurídicas a las realidades sociales del tiempo y del lugar, estaban en el meollo de los males que se pretendía exterminar. Apostando por el empuje y la prosperidad del pluralismo político, el uso alternativo del Derecho demostraba la hostilidad de la voluntad parlamentaria frente a los textos constitucionales que -vista la resistencia cuasinumantina del legislador originario- reclamaban un tratamiento quirúrgico de urgencia.

Una semiverdad -fundada en la rutina de las fobias históricas irreflexivas- sostiene que la tecnificación del vigente ordenamiento jurídico español dispensa de acudir a un uso alternativo del Derecho que se dice superado y proscrito. Algunos datos contradicen esta aseveración. Las operaciones constituyentes del Estado social y democrático de Derecho se valieron de la mediación -pacificadora y eficaz- de un uso alternativo del Derecho previgente, que, antes de fenecer, cumplió unas funciones de reparación sin cuyo auxilio el proceso de transición democrática no habría salvado importantes obstáculos de su trayectoria. La claridad tardía de la DD.(Disposición Derogatoria) $3 \mathrm{CE}$ dio a conocer que la supuesta octava ley fundamental del sistema previgente era, además de su verdugo enmascarado, la primera ley del nuevo Estado y que -para disipar las dudas sobre el particular- le correspondía eliminar los residuos de la legislación fundamental autoritaria viciados de inconstitucionalidad sobrevenida. Con tal aclaración, la LRP resultó ser-mirando atrás, sin ira- la pieza clave de un uso alternativo del Derecho que, accediendo a esta vía y no a cualquier otra impracticable, allanaba los caminos de la transición y limaba las asperezas del giro copernicano democrático. Con el uso alternativo rupturista, por privación o carencia de medios jurídicos idóneos, coexiste un uso alternativo institucional que el ordenamiento jurídico tiene a su alance y de cuya ductilidad, llegado el caso, puede aprovecharse.

La otra constancia -que transmite al pluralismo político la prontitud de que alardean sus protagonistas- es que el constituyente ha sancionado el uso alternativo del propio Derecho constitucional, considerando equitativo y saludable que el desarrollo legislativo de la misma norma de la ley fundamental - acatada por las ideologías instaladas en la escena políticosocial- se atenga, como es lógico, a las directrices de sus opciones específicas, y, a la vez, discrepe de las líneas del pensamiento y de la acción política - no menos constitucionales- que le son antagónicas y/o divergentes, y en comparación con las cuales no pueden ocultarse, al modo de una ingeniosa prestidigitación, las diferencias de sus entendimientos. El pluralismo político es, hay que repetirlo, la posibilidad de que los valores, principios y preceptos constitucionales - coasumidos sin disidencias sustanciales- admitan lecturas incompatibles entre si, pero acordes, sin perjuicio de ciertas erosiones laterales, con el tenor 
flexible de la letra y el espíritu de la carta política. De ahí, su traslación a los individuos y/o grupos sociales cuyos intereses demandan una atención connatural e inmediata.

No faltan ejemplos de ese uso alternativo constitucionalmente estimulado. El art. 9.2 CE admite ponderaciones varias -arbitrarias y no descabelladas-para alcanzar las metas de la realidad-constancia y no falsa añoranza o percepción voluntarista- y la efectividad -ejemplaridad y asombro despertados por su contundencia- de la libertad y la igualdad que se conjugan para dar paso a la justicia material y fortificar su recepción. La libertad y la igualdad pueden situarse en planos que normalizan sus interacciones y les asignan el mismo tanto de participación. Cabe que, en cambio, se primen las funciones de la igualdad material y que, partiendo de esta preferencia, las correlativas libertades se autorregulen y compensen la creatividad de quienes las inventan -descubriendo sus expresiones inéditas y preexistentes- $\mathrm{y}$ se disponen a experimentarlas. También es dable que, para no acentuar los desmanes de las libertades, se establezcan frenos o desigualaciones iniciales que mitigan esos inconvenientes. El uso alternativo de la cláusula transformadora y social sirve a los medios y fines de una sociedad pluralista cuya inserción en el modelo del Estado depende del peso específico y el concurso de las ideologías. Tendencias que, unas veces, difieren ostentosamente y, otras, son más o menos difusas o enojosas de identificar.

Otro ejemplo reside en el art. $14 \mathrm{CE}$, que-además de vedar las diferencias de trato carentes de una justificación objetiva y razonable- se ha utilizado para mejorar la condición de situaciones jurídicas que -aun fuera de los ámbitos de la sec. $1^{\mathrm{a}}$, cap. $2^{\circ}$, tít. I y el cap. $3^{\circ}$, tít. I CE- se benefician del trato y la tutela reservados a los derechos fundamentales y las libertades públicas. Del art. 24.1 CE se ha echado mano para lograr el mismo efecto, apelando a un uso alternativo similar a la figura que el Derecho punitivo llama concurso de normas o conflicto aparente de leyes penales. La aplicación de ambos preceptos -tildados de polivalentes- sirvió para ampliar el acceso al recurso de amparo instituido en el art. 53.2 CE y tantear algunas de sus innovaciones. $\mathrm{Su}$ frecuente interposición ha provocado invasiones -motivo de algún desconcierto para el común sentir de la ciudadanía- de la justicia constitucional en el ejercicio de la jurisdicción ordinaria, que ha reaccionado sin fortuna excesiva. Parece anómalo el efecto derivado de reconvertir, aunque se insista en que no son así las cosas, el recurso de amparo en una cuasicasación constitucional que controla unas aplicaciones de la legislación ordinaria cuya revisión no le compete.

Un supuesto heterodoxo proviene de aplicar una operación de uso alternativo del Derecho a la idea de información veraz que, según el art. 20.1 a) $\mathrm{CE}$, se comunica o recibe libremente por cualquier medio de reproducción. La descripción veraz de los episodios del mundo del ser, es, a primera vista y según la naturaleza de las cosas, la que -en sustancia y accidentes- coincide con el hecho histórico traído a colación. Se superpone, como un calco, a la 
realidad -no a la conjetura ni a la hipótesis- y reseña inconfundiblemente los acaecimientos constitutivos de la información transmisible. Informar verazmente es cumplir una obligación de fines o de resultado, cuya ejecución -idéntica, indivisible e íntegra- requiere ofrecer noticia fidedigna del suceso y de sus contenidos individualizadores, descartándose las versiones reñidas con la unidad y unicidad del hecho histórico que ha de difundirse. La información deja de ser veraz si quienes la cursan no describen cómo realmente acaecieron los hechos transmitidos y, para eximirse de responsabilidades, pretenden que, con cierta ligereza, se dé por buena una versión que haga las veces del relato adeudado a la opinión pública, en general, y a sus destinatarios, en particular. Apartándose de una lectura que parece pacífica y única, la tesis de la comprensión alternativa del art. $20.1 \mathrm{~d}$ ) CE brota de un pensamiento cuestionable y conversor de la obligación de fines o de resultado-que urge al informador- en una obligación de medios o de simple actividad. Ello descarga de agotar la consulta de las fuentes que fundan la veracidad de lo informado, si se acredita haber usado de una diligencia razonable y, ello no obstante, siguen en pie las objeciones sobre la absoluta verdad de los hechos. Información veraz bis, es la que -contradiciendo la verdad objetiva y exacta, que ha de respetarse, o disintiendo de ella- viene del informador que confiesa haber agotado su explotación de las fuentes de máxima fiabilidad. Ello le convence de la existencia de una realidad histórica que, según indagaciones posteriores, acaso no ocurrió tal y cómo se presentaba, pero que el agente informador da por buena gracias a la confianza que, sin más averiguaciones, le merecen aquellos testimonios. Al bastar con el uso de la diligencia exigible - sobremanera fatigosa- para comunicar la realidad y relativizar su verificación exhaustiva, se canonizan las noticias históricamente falsas o inexactas y se acepta un concepto dudosamente alternativo de lo que por información veraz debe entenderse. Se comulga con la devastadora máxima que reza "no dejes que la realidad se te anticipe y te arrebate el éxito de una noticia considerada buena y constitutiva de una sensacional información". Se exime de responsabilidad por el daño irrogado a los derechos fundamentales al honor y la intimidad de las terceras personas salpicadas por la información desorientadora o inveraz. Este uso alternativo del art. 20.1 d) CE vulnera el principio ontológico de no contradicción, prohibitivo de que «una misma cosa-nada menos que la verdad controvertida- pueda ser y dejar de ser al mismo tiempo».

Antes de que el acceso a la Europa comunitaria comprimiese su elasticidad, otras normas constitucionales admitían esta susceptibilidad pluralista. $\mathrm{El}$ art. $38 \mathrm{CE}$ acogía sendos entendimientos -respectivamente liberal y planificador- que eran incompatibles por hipótesis. Predecían, respecto a las economías de mercado, modelos y desarrollos de la libertad de empresa que diferían con sólo ensayar lecturas que, en voz alta, alterasen sus inflexiones orales o prescindiesen de una concreta puntuación ortográfica. El art. 131.1 $\mathrm{CE}$-donde el infinitivo verbal «planificar» no iba seguido del adverbio «de- 
mocráticamente», al igual que el art. $38 \mathrm{CE}$ citaba la "planificación» a secas y omitía su calificación de «democrática»- toleraba dos entendimientos. El primero autorizaba a restringir, si era del caso, los excesos de una libertad de empresa concebida como pieza exclusiva del modelo económico propuesto por el constituyente. El marco de la economía de mercado no era entonces una opción dependiente del decisionismo político, sino la única de las elegibles en ese orden de cosas. El segundo insinuaba que la libertad de empresa sólo era uno de tales caminos -a saber, el propio de la economía de mercadoy no descartaba las salidas extremas de la socialización económica o recetas afines. El recurso al valor superior del pluralismo político ungía inclusive la economía controlada -en régimen de normalidad o de excepción- por el omnividente aparato del Estado. Dígase si el art. 38 CE no encerraba la carga de profundidad necesaria para que, sin cortapisas, el legislador ordinario comprobase la existencia de las condiciones necesarias para intentar unos avances sociales espectaculares. Las repercusiones desencadenadas por la elección de uno u otro modelo económico serían múltiples e impredecibles. Las cosas han cambiado desde que la adscripción a la UE (Unión Europea Occidental constituida por el TUE, Tratado de Maastricht de 9 de febrero de 1.992) privilegia el modelo - primero tradicional, después lastrado por la crisis y ¿acaso dispuesto a resurgir? - de la libertad de economía de mercado, refundiendo el ¿retorno a la tradición judeocristiana? y el neoliberalismo insondable de los enigmas globalizadores.

El principio de primacía del Derecho Comunitario descalifica cualquier arbitrio autoritario de que se pretenda echar mano para reinterpretar el art. 38 $\mathrm{CE}$, porque el espacio económico de la UE se singulariza por la eminencia respetable de los derechos fundamentales de libertad de empresa y libre circulación de capitales. Son derechos que, parafraseando una dicción ya consagrada, pertenecen -como base y fundamento de su regular gobernación-a los artífices de la construcción europea y a la posteridad que constituyen las generaciones venideras.

La indemnidad convence de que el supremo valor de la justicia material no se ciñe a impregnar -desde el cielo de los conceptos éticos- un ordenamiento jurídico en que no ha penetrado, sino que traspasa este recinto amurallado y actua la supremacía que se ejercita en su interior. No es dogmáticamente indefendible -sí, retadora y sugestiva- la tesis favorable al control de la aplicación directa de la legalidad fundamental en nombre de una justicia material antecedente que se impone a sus principios y preceptos. El uso alternativo, de que se hace mérito, no es un arbitrio ocasional o extemporáneo, sino un anticipo que el pluralismo político maneja para no expulsar del área democrática las iniciativas que -viniendo de ideologías divergentes y de sus ofertas a una opinión pública cuya formación han asumido- sugieren la Política Legislativa y/o la autonomía de las personas y los grupos sociales que, cuando menos, tocan con la mano la oportunidad de sumarse a una línea común de pensamiento y de atenerse a sus orientaciones. 


\section{MANIFESTACIONES NOTABLES Y ESPECÍFICAS DE LA IN- DEMNIDAD PATRIMONIAL}

Una de las variantes de indemnidad recogidas por el constituyente se refiere a la plenitud del ordenamiento jurídico que evita los perjuicios anejos a la baja densidad de las fuentes primarias y a la subsistencia de lagunas dañosas para la comunidad a que se destinan. Otra suerte de indemnidad supone que ese Derecho pleno es algo más que válido, pues la justicia material ocupa el vértice del ordenamiento jurídico en cuyo interior ha penetrado. Valor supremo que -conglobando la libertad y la igualdad- se instala en el seno del ordenamiento y, lejos de limitarse a una asistencia descomprometida, controla y contrasta cuantos preceptos se le subordinan. Toda una rehabilitación de la equidad se sigue de estas proposiciones y de la vehemencia con que la cláusula transformadora y social del art. 9.2 CE las gratifica y hace suyas.

Junto a esta magna situación de indemnidad, el constituyente no descuida las indemnidades singulares que, por su modernidad o tradición, se explican y ocupan lugar en el contexto de las garantías que les acompañan.

Amén de la esplendidez políticolegislativa que entroniza la libertad y la igualdad, el art.9.2 CE no dicta a los poderes públicos obligaciones típicas y predeterminadas, sino que -con la elasticidad peculiar de la prudencia políticaprefiere hacer algo distinto. El ejercicio de las competencias y la concreción de las funciones públicas que implican, parten de una consigna general que, a imagen y semejanza de otros valores, las hace comprensibles y amables. El concepto jurídico indeterminado de poderes públicos sobrepasa -si los pasajes del texto constitucional se coordinan esmeradamente- la trilogía de la separación e independencia de los poderes clásicos. Ello anima la labor selectiva de aquellos supuestos y lleva a amplificar la máxima que afirmaba «todo poder único es despótico, no hay libertad donde no hay independencia y separación completa de poderes, un poder necesita ser controlado por otro poder»».

El compromiso de progreso de esa cláusula tiene que provocar la audacia saludable -no las quién sabe qué aberraciones demagógicas- de la acción legislativa que contempla el art. 66.2 CE, de la originalidad y la bondad políticas - no de la inercia rutinaria- del decisionismo gubernamental y de las Administraciones Públicas a que aluden los arts. 97 y 103.1 CE, y de los afanes novedosos -si desiste de seguir circulando por senderos trilladosdel Poder Judicial para diferenciar -aumentando su productividad moral- la efectividad maximalista de la efectividad minimalista y - ¿cómo no?- de la eficacia formal y simplificadora. Tal es la prospección, a gran escala, de lo que, más adelante, preconiza el art. 53.3 CE para los principios en que el cap. $3^{\circ}$, tít. I CE enumera -adelantándoles y, a veces, llamándoles derechos, como hacen los arts. 43.1, 44.1, 45.1 y $471 \mathrm{CE}-$ los objetivos más acariciados de un proyecto de transformación y de cambio. El art. 9.2 CE -que no habla de «obligaciones» o «deberes»- utiliza el indicativo «corresponde» para esbozar una propuesta innominada de obligaciones naturales que los poderes públicos reseñan, actualizan o añaden a las ya existentes. Estas obligaciones 
naturales -encumbradoras de los niveles de la igualdad y libertad efectivas que subliman la justicia material- agrandan los espacios de la indemnidad, pues colman los vacíos en que, disimulando su presencia y sus rechazables intenciones, se ocultan los riesgos de quebranto de los intereses generales.

Cabe que el legislador infrinja el supremo valor de la justicia -impuesto a su decisionismo- o conculque, con graves fisuras, los principios y/o los preceptos constitucionales. No es inusual ni sorprendente que las Administraciones Públicas dejen de someterse plenamente a la ley y al Derecho que, con más frecuencia de la tolerable, descuidan y/o pasan por alto. De ahí, el recordatorio, avalado por la experiencia histórica, del art. 103.1 CE, además del encarecimiento general del art. 9.1 CE. Puede ocurrir también que los jueces ordinarios se desmarquen del espacio reservado al imperio de la ley o desoigan los llamamientos a su independencia. Se da entonces una reacción arbitraria que -vedada en el art. 117.2 CE- contraviene las pautas rectoras de la moralidad y juricidad de sus comportamientos. Se conducen de modo inconsecuente con el apuntado para adecuar sus actitudes y sus hábitos al texto constitucional y al resto del ordenamiento jurídico. Las peripecias de este corte dañan, directa o indirectamente, los intereses afectados por unas acciones u omisiones que se apartan de sus finalidades.

Las conductas arbitrarias de los poderes públicos pueden disfrazarse de audaces operaciones de transformación que invaden la inmensa tierra llana del art. 9.2 CE. No se distinguen -si se atiende a la constancia de lo superficial- las acciones solventes de transformación, de las piruetas que, jactándose de novedosas, sólo merecen la denuncia indulgente del escaso fuste que las caracteriza. Para paliar este frenesí y evitar que el art. 9.2 CE degenere en fuente caprichosa o instrumento torcido de posturas inconstitucionales, el art. 9.3 CE vuelve a la tierra firme del normativismo que no pretende abandonar. Prohibe -con los medios favorables al fin perseguido y al margen de tentativas llamadas al fracaso- la arbitrariedad de los poderes públicos que destrozan el sentimiento constitucional e inutilizan su puesta al servicio del Estado social y democrático de Derecho. La garantía se extiende a la incursión en responsabilidad que, según la estructura y funciones de aquellos poderes, imputa las consecuencias de los actos causantes del daño y ocupa los espacios en que la indemnidad se instala para subsistir.

La responsabilidad por actos legislativos cabe si se accede a la tesis moralizadora-acogida con reservas- de que la introducción e irreversibilidad del supremo valor de la justicia, en el seno del ordenamiento jurídico, hieren de muerte la supervivencia de las normas jurídicas que se le opongan o la contradigan. Como el control máximo del Derecho Positivo sigue ejerciéndose a través de la legalidad fundamental y no del bloque de moralidad legalizada que se le antepone, se precisaría de una investigación comprometida para fabricar un discurso - documentado y persuasivo-sobre el retorno más reciente de cuantos-incesantemente, es decir, sin demoras ni treguas-registran las normas del orden natural. 
La responsabilidad del Gobierno y de las Administraciones Públicas conecta con la indemnidad preventiva y terapeútica, avalada en los arts. 103 y $106 \mathrm{CE}$, al obstar a la producción y/o las consecuencias de los daños causados por el funcionamiento anormal de los servicios públicos, que, además de las prestaciones de esta procedencia, comprende los actos políticos del Gobierno que producen efectos derivados de la infracción del ordenamiento jurídico.

No se olvide, en fin, que, según el art. 117.1 CE, la justicia se administra por Jueces y Magistrados responsables y que la responsabilidad por errores judiciales o funcionamiento defectuoso de la Administración de Justicia se instituye en el art. $121 \mathrm{CE}$.

La indemnidad patrimonial se manifiesta en el deber de respetar el contenido esencial o núcleo invulnerable de los derechos innatos. Lo que el art. 53.1 CE exige del legislador - a saber, la observancia de ese contenido- es algo a que se obligan cuantos se inscriben en la órbita donde, con más o menos éxito, se ejercitan los derechos así localizados. El contenido esencial significa lo que, perceptible y unánimemente, corresponde al haz de facultades que integran el activo del derecho en cuestión. Consta de manifestaciones que diferencian el derecho o la libertad analizados, de los demás que completan la urdimbre de los derechos reconocidos. Tiene, para el caso de que fracase su satisfacción en forma específica, la común consecuencia del resarcimiento del perjuicio o la reparación íntegra del daño, esto es, de la pérdida sufrida más la ganancia dejada de obtener que menciona el art. 1.106 C.c. El art. 53.1 CE refrenda un principio inherente al reconocimiento de cualquier derecho y al contenido esencial que le individualiza, incluida la procedencia de una justa reparación y no de un subrogado arbitrario y simbólico, cuando -a tenor de los arts. 1.156, 1.167 I y 1.169 I C.c.- no se asegure la satisfacción dependiente de la identidad, indivisibilidad e integridad del cumplimiento. Las obligaciones naturales -desprovistas de acción procesal para exigir el cumplimiento en forma específica o enmendar su desatenciónson una excepción a la generalidad de este mecanismo.

El art. 45.3 CE da por supuesta la regla general del resarcimiento, al convertir en positiva y exigible la obligación natural de conservar y defender el medio ambiente necesario para el desarrollo de la persona, que el art. 10.1 CE declara fundamento del orden político y de la paz social. Se espera que el legislador ordinario determine las condiciones en que, ocurrida dicha violación y lesionada la indispensable solidaridad colectiva, proceda acordar la reparación del daño causado.

Un aspecto notable de la indemnidad patrimonial atañe a la privación de los derechos subjetivos en virtud de la expropiación forzosa. Parece indiscutible que, a causa de una modificación producida en el trámite de la ponencia constitucional e imputable a protagonistas cuyas identidades nadie ignora, el art. 33.3 CE ha minorado la extensión tradicional de la garantía expropiatoria. La conmutatividad del negocio jurídico en que consiste la venta forzosa, 
requería que -para respetar la exigencia de la causa que cita el art. 1.274 C.c.- la indemnización compensatoria de la privación sufrida o el precio del bien enajenado se abonase antes de la desposesión del sujeto expropiado. El art. 33.3 CE prescinde de esta garantía - tocante al mínimo de conmutatividad del hecho expropiatorio- y se ciñe a indicar que la privación de bienes y derechos no puede ser confiscatoria, porque mediará siempre la indemnización correspondiente, aun cuando no sea justa su cuantía. Resulta incomprensible -si la falibilidad humana no estuviese por medio- que, elevada la justicia al rango de supremo valor del ordenamiento jurídico, el art. 33.1 CE suprima dicho requisito con una iniciativa sorprendente y preparatoria de un ensayo de legislación de caso único. Allí donde, de antiguo, el pago de la indemnización, además de preceder al desapoderamiento del bien expropiado, tenía que ser justo, esta calificación se suprime y se afirma -sin aludir a la exigencia de justicia- que el resarcimiento será el "correspondiente"- adjetivo oscurecedor y arbitrario- a la enajenación en curso. Término que, para mayor empobrecimiento del precepto, ni siquiera contiene un concepto jurídico indeterminado y sólo da a entender aquello que, aun expulsando el adjetivo, se comprende sin dificultad. Cierto que, acudiendo al carácter privilegiado del TPCE, puede opinarse que la voz «correspondiente» se escoge para remitirse al art. 1.1 CE y concluir que, faltando el precio justo, la expropiación no es tal y sí una confiscación encubierta con abominable descaro. Esta miseria correctora no fue una incidencia inevitable ni nació de una ligereza u omisión sufrida durante el proceso de factura constitucional. Provino de una iniciativa -cuyas intenciones formaron parte de un secreto a voces- que, andando el tiempo, produjo en cadena los efectos previstos. A saber, lo excepcional de un acto expropiatorio respaldado por una norma jurídica de caso único y afianzado con complicidades generosamente repartidas. Hubo repercusiones relativas a la premeditación del golpe que ello suponía, a lo precipitado de su adopción rocambolesca, a las irregularidades formales que salpicaron su curso, a las utilidades que reportó a los beneficiarios preseleccionados y a los interrogantes -morales, jurídicos y económicos- que siguen sin despejarse ni mostrarse interés en que lo sean. Todo ello, para pésima conciencia y oprobio de quienes planificaron la operación, de su equipo de cooperadores y de los terceros cuya voracidad aceleró el hundimiento de los llamados a sufrir la derrota. El art. 33.3 CE se erigió en un «vae victis»- ";Ay de los vencidos»que, amén de sonrojar muy mucho, fomenta otras elucubraciones.

\section{GARANTÍA DE LA INDEMNIDAD FORJADA EN LA DEFEN- SA SISTEMÁTICA DEL FUTURO DE LA EXISTENCIA INDIVI- DUAL}

La selección que ahora se ensaya, se va a cerrar examinando el futuro individual -asociado a los otros futuros que con él coexisten- como una de las realidades ascendidas a la vida jurídica, merecedoras de tutela y protegidas frente a las consecuencias de su menoscabo. Hay un régimen público de 
Seguridad Social que -imposible de asentar directamente en la sede de derechos fundamentales que es el art. 17.1 CE-tampoco ha de contraerse a los límites que impone al art. $41 \mathrm{CE}$ su residencia en el pasaje que el cap. $3^{\circ}$, tít. I CE rotula «De los principios rectores de la Política Social y Económica». No faltan argumentos para enclavar el derecho de todos los ciudadanos a la Seguridad Social en el espectro de los derechos fundamentales y reconocer la naturaleza que les corresponde en el contexto -humano y democrático- de los valores eminentes.

Una novedad del que aspiró a ser texto constituyente europeo y, a falta de ratificación unánime, se esfumó demasiado pronto, consistió en llevar a la CDFUE (Carta de los Derechos Fundamentales de la Unión Europea, incoada por el Tratado de Niza de 7 de diciembre de 2000) el título de Solidaridad que, en el elenco de los derecho sociales maltrechos hasta entonces, determinó que el art. 94 TCUE (Tratado de 29 de octubre de 2004, por el que se establece una Constitución para Europa)) confiriese al derecho a la Seguridad Social el carácter de derecho fundamental. Estímulo que, pese a su potencial de excitación técnicojurídica, reveló la parca ilustración con que -al encomiarse la excelencia del texto frustrado por falta de unanimidad de los Países Miembros- los sindicatos del primero de los Estados soberanos que convocó la preceptiva consulta popular, pasaron por alto tan significativa novedad y compartieron, con rigidez cadavérica, la rudeza informativa de la propaganda gubernamental.

Así las cosas e independientemente del fracaso político sufrido, recuperó su fuerza de obligar el art. 136 I VCTR (Versión consolidada del Tratado de Roma, modificado por el TA, Tratado de Amsterdam de 20 de octubre de 1997), de cuya lectura se colige que el compromiso de realizar una Política Social adecuada obliga a los Estados miembros a tener presentes - exhumando su verdadero rostro y dotándoles del consiguiente tratamiento- los derechos sociales fundamentales contenidos en la CSE (Carta Social Europea de 18 de octubre de 1.961) y los que, al enunciar los derechos sociales de los trabajadores, reconoce la CCDSFT (Carta Comunitaria de Derechos Sociales Fundamentales de los Trabajadores de 8 y 9 de diciembre de 1989). Esta remisión recupera el más reciente espectro del Derecho fundamental comunitario -cuya versión y validez jurídica reviven tras el revés electoral del TCUE- y diseña el derecho a la acción protectora de la Seguridad Social como un derecho fundamental acompañado de sus atributos específicos. Aunque la conclusión no despierte el entusiasmo de los euroanalistas e incluso se minimice su alcance, nacen, en su virtud, las obligaciones estatales de emprender las pertinentes reformas constitucionales y enmendar una distribución incompatible con el carácter asignado al derecho a la Seguridad Social por la naturaleza de las cosas y no por las decisiones erráticas del voluntarismo político. El Derecho objetivo de los Estados miembros de la UE (Unión Europea) no puede, so pena de infringir el principio de primacía del Derecho Comunitario, mermar la dignidad ni mudar la esencia de una 
institución que -como el derecho de todos los ciudadanos a la Seguridad Social- las normas comunitarias vigorizan inequívoca y suficientemente. Lo hacen cuando -por vía de hallazgo y pormenor de sus notas de identidad- le asignan una tutela más intensa que la conferida por la legalidad constitucional o la legislación ordinaria del Estado. Es preciso que las manifestaciones del Derecho objetivo del régimen público de la Seguridad Social tengan la consideración de un derecho fundamental inherente a una solidaridad bien entendida y expresiva -como reza el Pr. (Preámbulo) CDFUE- de un valor perteneciente al bloque universal e indivisible de la dignidad, la libertad y la igualdad de la persona humana instalada en el centro de un espacio de seguridad y de justicia. Ello dista de prejuzgar que, gracias a una milagrosa conversión o acto de fe, los poderes públicos de los Estados miembros -aferrados a los cánones economicistas- compartan esta conclusión con entusiasmo. Los episodios recesivos y críticos demuestran que al, reoscurecerse el panorama, no es gratuito ni descabellado el pavor que, en ese y otros temas explosivos, despiertan las conminaciones y ocurrencias del neoliberalismo salvaje.

El aspecto de la indemnidad a que se mira finalmente, recuerda que la cobertura de los derechos individuales de corte clásico se contrajo a las vicisitudes incidentes en la existencia diaria de la persona individual, objeto de las dosis de tutela jurídica admisibles y expuesta a menoscabos que -aunque reparables mediante las normas rectoras de la responsabilidad correspondiente- carecían de referencias racionalizadoras y sedantes, cuyo bagaje informase verazmente sobre la magnitud y el ritmo de sus transformaciones. Surgieron después las interpelaciones del pluralismo social, cuyo futuro condicionaba las constantes de su definición y las variables de su engrandecimiento. Influyó también la mala conciencia de que provenía la herencia-plagada de dudas y de deudas- que la sensibilidad éticopolítica del Estado Social y democrático de Derecho obligaba a aceptar para olvidar, pasando página cuanto antes, la posición apática del Estado de Derecho liberal burgués.

El concepto de Seguridad Social abarca un cuerpo de doctrina que antepone los perfiles del bien jurídico emanado de la protección de un interés situado en vanguardia de las auténticas demandas sociales y expresivo de la rebelión contra la terquedad con que se desoyen sus quejas. Se parte de que la pluridimensión de la vida o condición humana -que la jerga del existencialismo emparejaba con la angustia de "estar caídos en el mundo»- no es sólo un valor individual defendible frente a los daños imputables al sujeto causante. Tal condición es una parte -no siempre separable- del todo de las existencias personales que, coasumiendo la utilidad y soportando las cargas del presente, se abren a la futura planificación o garantía de los episodios que antaño se llamaron riesgos y hoy equivalen a contingencias previsibles e intuidas con dosis variables de fatiga profética. Hay que obtener un cuadro-lo más detallado y fiable- de la frecuencia de esos episodios, de su lesividad y de las reacciones colectivas de la resistencia a su irrupción. Las indemnida- 
des fundadas en la verificación de la plenitud del ordenamiento jurídico, en la presunción de justicia de sus normas, en su sometimiento a los controles de una moralidad legalizada y en los modelos de reparación del Derecho de daños, se completan con un último testimonio. Se entiende que -ponderadas las menciones que los arts. 10.1, 25.2, 27.2 y 45.1 CE dedican al pleno y libre desarrollo de la personalidad-su progreso consta de fases y oportunidades que, conforme a la idea filosófica del devenir que impera sobre la del ser, perduran y se complican en el tiempo. La existencia individual, lejos de congelarse en los momentos óptimos de su crecimiento, evoluciona para bien o para mal del futuro que le aguarda hasta el fin de sus días. Ese futuro hace historia a unos ritmos que, lejos de producir efectos petrificadores, arrancan de las compulsiones externas o del arrojo emprendedor del yo de la persona. Cada momento de su porvenir soporta una elección a que se aferra o que la desafía con alternativas de asimilación o resistencia. Sin omitir ni desdeñar la circunstancia de que la persona combate para continuar siendo ella mis$m a$. El razonamiento, aunque primario y tosco, basta para convencer de que ese porvenir no es sencillo, porque abarca todos y cada uno de los momentos en que la existencia humana se expone a la prueba de su definición y a las peripecias de su interés legítimo en lograr la aquiescencia jurídica de su relevancia. El género próximo aplicable a esas vicisitudes se conoce con el nombre de seguridad. La expansión de la demanda de seguridad determina el carácter social -colectivamente racionalizado- de la tutela esperada y exigida. Un régimen público de Seguridad Social, como el previsto en el art. 41 CE, se propone -aunque, para enmascarar los apremios de este fin, circulen pretextos y verdades a medias- llevar a sus confines más justos un presupuesto capital. El de que la cointegración del futuro de cada existencia personal se convierta en un bien jurídico regulado por sus portadores y por el sentimiento de reciprocidad fraternal que remueve la solidaridad desgastada y equívoca de los demás. Los atentados contra ese futuro lesionan sus valores jurídicos y causan daños patrimonialmente resarcibles.

Una lectura sosegada del art. $41 \mathrm{CE}$ revela cómo y en qué términos se concibe el aspecto de las inmunidades avaladas constitucionalmente. Con independencia de que su toma de visión se inscriba en circunstancias de prosperidad económica -a las que no hay retorno-o de una crisis que, siendo en principio su contrafigura, derivó luego en sucedáneos de difícil diagnóstico y borrosos contornos. Mientras algunos de éstos sobreviven, otros emergen aparatosamente para volver a confundirse. Ello tiene lugar bajo la rúbrica de la globalización que, a fin de cuentas, denota cómo lo denso y álgido de los problemas comunes se enrarece para aumentar la lista de sus interrogantes y embrollar los problemas que, en vez de conclusiones comprensibles, alimentan las contradicciones que, en muchos casos, pueden evitarse. No se está lejos, si no se ha producido ya, de la inmersión en una ceremonia de la confusión donde se mezclan obviedades - que nada suman a lo ya temido- y fobias que enturbian el panorama divisado, intoxicando una meridiana dis- 
tinción entre lo que, con probabilidades de fructificar, se debe, se puede y se tiene el propósito de llevar a cabo.

Retornando al grueso de estas reflexiones, el art. $41 \mathrm{CE}$ asigna a los poderes públicos el papel de sujetos activos de las operaciones sociales a que da cabida. Quiere decir que, cuando menos y con independencia de los poderes que ejerciten la función asignada, siempre se está pendiente de la cláusula de transformación del art. 9.2 CE y, sin retroceder, se encomienda la gestión de esta indemnidad a sujetos semipúblicos o poderes de hecho. Sin perjuicio de las aportaciones de los agentes del pluralismo político que son los partidos según el art. $6 \mathrm{CE}$, de la promoción y defensa de los intereses - conexos con la indemnidad-por los sindicatos que, conforme al art. $7 \mathrm{CE}$, los activan o se los apropian, y de la asiduidad de los grupos y/o las comunidades que atentos a la gravitación del art. 9.2 CE y a la voz de «proa adelante»- coadministran las adquisiciones de la sociedad pluralista.

La promesa se dirige a todos los ciudadanos y requiere una reinterpretación acorde con las realidades sociales que la motivan y van aconteciendo. A efectos de acotar la zona de indemnidad coherente con este entendimiento, se consideran destinatarios a cuantos se inscriban de presente y de futuro en el marco de eventual lesividad que está en las inmediaciones de las contingencias protegidas. No se trata de aferrarse a los tópicos de la limitación e insuficiencia de recursos, sino de subrayar dos órdenes de realidades influyentes. Una de ellas, el achicamiento del mundo que correlaciona las contingencias y exige formas protectoras más eficientes e ingeniosas, en cuanto derivadas de las mismas, aunque su dispersión geográfica se aproveche para desoírlas. Otra, el ejercicio del derecho de comunicación, que, amén de su virtud intrínseca, es impulsado por ese achicamiento y, en la medida de sus ímpetus, goza de inconvenientes y ventajas. Ambas magnitudes se aligeran si se dispone de un aparato internacionalizado, purgado de banalidades retóricas y consecuente con las advertencias de un fenómeno aliado con la racionalidad y sentido común. No es inteligente ni honesta la tentativa de explotar unas realidades sociales que, sin visos inequívocos de prosperidad, se califican -con la laxitud del pensamiento de deseo- de estimulantes y viables, cuando las evidencias negativas de la coyuntura desautorizan un optimismo exagerado.

Se promete un régimen público expresivo de que, para proveer a la indemnidad del futuro, el Estado social y democrático de Derecho no transigirá con los típicos y tópicos cantos de sirena y, pendiente de dichas realidades, defenderá una más de las parcelas del Derecho necesario. Cabe, unas veces, entender que ha llegado la hora de que los ciudadanos asuman directamente esos gravámenes, porque, a causa de la madurez adquirida, quedaron atrás las circunstancias que, para fomentar el progreso de las libertades, pertenecían a la presuposición del art. 9.2 CE y explicaban la prosecución transformadora. No falta quien sostiene que - como parte del futuro vislumbrado- sobran argumentos económicos para concluir que, a causa del retorno globalizador y 
neoliberal, se ha dislocado la base del negocio y es el tiempo de liberarse de esos compromisos.

Queda en pie una de las premisas del Estado de Bienestar que, aunque sigue concibiendo ese régimen como un sistema de previsiones arduas que amenaza con desmoronarse, no lo hace de momento y le aloja en el repertorio de los desarrollos legislativos más urgentes. Mantener el régimen público, no obstante su propósito de indemnidad colectiva, admite un entendimiento alternativo que sopesa las opciones insinuadas por el valor superior del pluralismo político. Desde una posición minimalista, se hace saber que los poderes públicos no arrían la bandera protectora de las aspiraciones de la Seguridad Social ni traspasan a terceros las competencias relativas a la gestión del bien jurídico en que el futuro de la persona individual consiste. Otra posibilidad -menos afortunada en la práctica, pese a las consideraciones que, sobre el destaque y eminencia del derecho, han precedido- propone una lectura favorable a la tesis de que, además de subsistir la arquitectura de un sistema de Seguridad Social racionalizado y solvente, se conservarán los avances que-según el postulado «siempre más, nunca bastante»-reflejaban el triunfo del principio de irreversibilidad. Esta salida -parte de las ilusiones truncadas del pasado- se ha clausurado definitivamente y su pretensión de indemnidad ha causado baja en las añoranzas políticolegislativas y en los panoramas tocados del ala por las irrupciones globalizadoras y el relieve adquirido por la noción de sostenibilidad.

El daño irrogado al futuro de la persona individual tiene otra característica. La compensación de los daños causados en los episodios comunes de la vida de relación lleva el nombre de indemnización o resarcimiento y corre a cargo del deudor responsable por un título jurídicamente válido para acreditarlo. La compensación del daño ocasionado al presente y el porvenir del individuo se denomina prestación social, pues los acaecimientos generadores del perjuicio son inseparables del pluralismo de la sociedad y se atienen a una periodicidad de contingencias avaladas por las prospecciones estadísticas. La compensación usual de cualquier daño - prevista de antiguo en el art. 1.105 C.c.- se rotula de indemnización, pues la consecución de sus auxilios interrumpe el menoscabo pendiente de resarcimiento.

La indemnidad garantizada por la acción protectora de un sistema de Seguridad Social es más reducida que la tradicionalmente asegurada por la compensación total de los daños causados, pues una y otra descansan en presupuestos diferentes. La indemnidad clásica provee a la reparación íntegra del daño, no sólo por tratarse -como hace notar el art. 1.157 C.c.- de un atributo de la deuda de responsabilidad contraída, sino también porque el art. 1.106 C.c. se refiere a dicha integridad. El daño sobrevenido en cada caso determinante -cualquiera que sea la fuente de la obligación cuyo tenor se infringe- de la incursión en responsabilidad y de la inexorabilidad del cumplimiento equivalente, brota de ese acontecimiento y su cuantía comprende el valor de la pérdida sufrida más la ganancia dejada de obtener. La justicia 
de la reparación se satisface atribuyendo a cada perjudicado una magnitud indemnizatoria que comúnmente difiere en cada caso. Se singulariza por la afectación de todos los bienes presentes y futuros del deudor a los efectos de la responsabilidad patrimonial universal que configuran los arts. $1.111 \mathrm{y}$ 1.911 C.c. Las prestaciones sociales, que aquí y ahora se comparan, se rigen por criterios distintos de los inherentes a la reparación íntegra del daño. Su accesibilidad económica no casa con la irrestricta persecución de los bienes y derechos del deudor, ni con la amplitud autorizada por el principio de responsabilidad patrimonial universal. El canon de limitación y equitativo reparto de recursos lastró, en los momentos más eufóricamente reivindicativos, la victoria del dogma de irreversibilidad de las adquisiciones sociales, porque las dimensiones de la crisis del Derecho de las relaciones de trabajo lo impusieron así, reemplazando el imperio de la rigidez por el fuero de la flexibilidad.

La interdicción de revocar los niveles de indemnidad conseguidos pasó a coexistir con la moderación de los medios de financiación del sistema, cuya cualidad de deudor no soportaba el componente de integridad a que se sujetaban las indemnizaciones de Derecho Común. La nota de suficiencia las imprimía carácter y las distinguía de aquellas indemnizaciones. La suficiencia de una prestación social consistía en su aptitud -condicionada por la cuantía dineraria de su auxilio- para aproximarse al importe de la reparación íntegra del daño. Las prestaciones sociales eran más suficientes a medida que acortaban esa distancia y respetaban unos límites cuya razonabilidad dependía de la asignación de los recursos restringidos. La prestación social se estimaba insuficiente si admitía una diferencia notoria o muy lesiva con la cifra indicada. La irreversibilidad de los beneficios sociales y la suficiencia de las prestaciones han sido conceptos de manejo engorroso a la hora de graduar sus oportunidades y establecer sus objetivos de progreso.

La suficiencia de las prestaciones -que parece un concepto relativamente determinado, pese a la dificultad de fijar el punto de inflexión de sus definiciones- adquiere otro sentido al incoarse la crisis económica y advertirse su impacto en el sistema de la Seguridad Social. Prestación suficiente no es ya la surgida de una formulación resbaladiza o laxa del adjetivo que sigue al sustantivo, sino la que, adjudicándole una evidente utilidad compensatoria, los poderes públicos invisten de esa cualidad. Una presunción de acierto acompaña entonces al ejercicio del decisionismo político. El valor superior del pluralismo político da entrada a una definición que, aunque susceptible de objeciones, se prevale de la elasticidad justificante de las reinterpretaciones $\mathrm{y} / \mathrm{o}$ de los descubrimientos de las proposiciones latentes en las normas jurídicas que las disciplinan. No parece que los arts. 35.2 y $40 \mathrm{CE}$ concedan el mismo alcance a los niveles de suficiencia que respectivamente se predican de la remuneración de la fuerza de trabajo y de la reparación del daño causado por el advenimiento de una contingencia protegida. 
La indemnidad que aquí se advierte, cubre las privaciones o defectos llamados situaciones de necesidad, conceptualmente ajenas a la causa de inculpabilidad del Derecho Penal y convenientes a las condiciones de las personas físicas que, tras asociar sus esperanzas a la prosperidad de un futuro compuesto de bienes variables, quedan desposeídas de todos o parte de los arrebatados por la producción de una contingencia dañosa. Lo demoledor de la crisis económica obliga a echar de menos cuanto se hallaba indisolublemente unido a la visión del porvenir, a sus horizontes históricos y a las composiciones de lugar hechas para insertarse en ellos. Se deterioran situaciones vinculadas al proceso del desarrollo pleno del futuro y de la perfección del bien jurídico a la carta en que el proyecto se concentra.

Ello es tanto como saber en qué consiste el escenario intuido y hasta dónde llega un espacio de tiempo decadente o inundado de ambiciones factibles. Algo que, según las perspectivas y los pasos dados para satisfacerlas, fraguará -con el paso del tiempo- abundantes reflejos y experiencias. Las situaciones de necesidad constituyen la parte del daño -no, como es claro, su totalidad- que se resarce con las prestaciones sociales dependientes de los requisitos -razonables y justos, tecnificados y complejos- que conciernen a la financiación y el alcance de la protección otorgada, sin descender a exigencias de culpabilidad extrañas a la naturaleza y los automatismos del sistema. El daño íntegramente reparable -según la patología de la situación jurídica afectada y la contravención del tenor de la obligación como fuente o título del resarcimiento- se compensa con la indemnización que encaja en la doctrina general del cumplimiento equivalente de las obligaciones civiles. La indemnización repara en el proceso de producción del daño y en la dosis de voluntariedad requerida para su atribución al sujeto causante.

Una precisión viene al caso. La protección de esta especie de la indemnidad no se aparta de un dato que el art. $41 \mathrm{CE}$ tiene en cuenta al introducir el complemento circunstancial encerrado en el giro «especialmente en caso de desempleo». Quiere decir que las cuestiones de presente y de futuro que convergen en esa indemnidad, también pertenecen a la escena del drama que ofrece el deterioro del derecho al trabajo estampado en el art. 35.1 CE. Derecho que no entraña la facultad o el poder jurídico -típicos de la traza de ciertos derechos públicos subjetivos- de obtener una ocupación procurada por los poderes públicos que -salvo lo previsto en el art. 25.2 CE para los condenados a pena de privación de libertad-no sobrellevan esa carga. Es criticable que se dé aquí una excepción a la regla del art. 35.1 CE, en vez, como parece lógico, de una ejemplificación del contenido esencial o núcleo invulnerable del derecho individual a la reinserción de los penados. Estos acumularían las facultades consistentes en acceder a un mercado de trabajo homogéneo y libre de restricciones arbitrarias, iniciar y mantener contactos con los empresarios oferentes en condiciones dignas de comunicación e igualdad material, debatir y contrastar las preferencias que motivan los intereses de la incorporación a uno u otro proceso productivo, perfeccionar el contrato de 
trabajo mediante la emisión de un consentimiento exento de vicios, obtener ocupación efectiva en el curso de la relación individual constituida y no verse injustamente apartados del empleo que se desempeña.

El adverbio «especialmente» admite dos entendimientos fecundos a la luz de la elasticidad interpretativa que autoriza su enclave en el art. 41 CE. Si se avista retrospectivamente el contexto de prosperidad que revelaban las incidencias optimistas del Estado social y democrático de Derecho, el desempleo -en que el giro adverbial ha reparado- es aun la especie que los postulantes de plena ocupación -que el art. $40 \mathrm{CE}$ pone cautelosamente en tela de juicio- reputaban un estigma ofensivo para la esplendidez y el espíritu social del Estado de Bienestar. Transigían con ello como si se tratase de una experiencia homeopática. Semejante intuición o advertencia tocaba el punto álgido de una economía que, vislumbrando la crisis económica, hacía temer que el desempleo engrosaría -veloz y escandalosamente- la lista de esas contingencias. El entendimiento del énfasis que el uso del adverbio imprime a su proposición, indica que, ante un incremento alarmante de la contingencia anunciada, los poderes públicos deben apresurarse a conjurar los perjuicios que origina, paliando los males de su repercusión en el mercado de trabajo y el tránsito social de sus consecuencias negativas. No vale mirar hacia otro lado y obstinarse en los hábitos de no decir verdad, cuando la desocupación incrementa la desolación y el empobrecimiento en un sistema protector que, lejos de combatir la inmersión en la crisis económica con criterios persuasivos y eficaces de planificación, contempla impávido sus devastadores deterioros.

La situación descrita alarma menos que la que el giro adverbial refiere a una crisis que, lejos de atisbarse entre luces y sombras, exhibe -descarada y descarnadamente- los antagonismos subyacentes a sus invasiones. Las etapas divisorias de sus experiencias dieron lugar a la rotulación de los períodos críticos que, agravando las dificultades de diagnóstico, ya pertenecen a la historia. Son ellos la emergencia o advenimiento impensable y pasmoso de la crisis, la contemporización con el compañero de viaje que la crisis implica, el ejercicio de las libertades económicas y las peripecias del empleo, la instalación resignada y paciente en el cautiverio de la crisis, la irreversible inmersión en la crisis, la crisis disciplinar y la recivilización crítica -en su acepción más censurable- de un Derecho Social cuyos espasmos agónicos derruyen la solidez de su prestigio. Es aquí donde el adverbio de modo «especialmente» pierde su significación prudencialista y/o preventiva, para adquirir otra que, con crudeza inusitada, denuncia cómo el hecho de la crisis económica y la acritud del desempleo alimentan reacciones colectivas de indignación y repugnancia. La indemnidad no se consigue encareciendo la previsión solícita de los poderes públicos, sino apremiándoles a que, ante la entidad y el riesgo social del desempleo, la suficiencia de las prestaciones devenga una medida indispensable y se complete con otras que muestren la libertad legislativa de decisionismo político. Técnicas que inicialmente asin- 
tieron al principio de continuidad en el empleo -dando por extinguida una estabilidad imposible de recuperar-y a su fomento con soluciones temporales que no disuadiesen a los titulares de la libertad de empresa -sancionada en el art. $38 \mathrm{CE}-$ de proseguir sus escabrosas aventuras. Debían condescender con períodos rotatorios que alternasen la actividad retribuida y la inactividad coexistente con una voluntad de trabajar insatisfecha. Hoy por hoy, se constatan, a escala mundial, los descompromisos de los poderes públicos - entrenados en silenciar lo que piensan hacer de inmediato y dispuestos a demorar lo prometido a largo plazo- que han dejado de proveer a una indemnidad arruinada por la extenuación de las relaciones de trabajo. De ello dan fe el arrinconamiento sindical de las funciones decisorias de la negociación colectiva y la desprotección individual para obtener y conservar un bien que, como el empleo, escapa al control eficaz de los agentes sociales encargados de su promoción y defensa, siquiera olvidadizos de tan graves responsabilidades. Estas dos versiones plausibles -una de ellas históricamente superada y pospuesta-representan respectivamente el anticipo o la visión profética de la indemnidad y la insistencia terapeútica para contener el alud de una contingencia virulenta. La primera de ambas descubre la amenaza de un mal que la Política Social de la prosperidad juzgó modesto y remediable, mientras que el tratamiento de la crisis le considera inmisericorde y destructivo. La segunda predice que, tras la irrupción masiva de dicha contingencia, la suficiencia de las prestaciones sociales no sólo ha de compensar la situación de necesidad protegida, sino que las reglas de su determinación cuantitativa -eco de las acciones que propugna el art. 9.2 CE- son inseparables de la necesidad de ponderar el perjuicio causado y corregir sus consecuencias negativas. Dejando de ceñirse a la tónica de protección estricta, enfrentan con el deterioro de derechos que la legalidad fundamental acoge y que los afectados no siempre pueden asumir y ejercitar con un mínimo de energía. Las intransigencias de la economía transmiten un carácter formal e inaccesible -con todas las frustraciones que supone el haberlas tocado con la mano- a las libertades que se desvanecen. Así ocurre con los derechos a la vida y la integridad personales, a la educación y a la existencia familiar de que se ocupan, entre otros, los arts. 15, 28 y 39 CE. Ello causa una reducción de la dignidad personal -modelo del crédito antropocéntrico en el que esos y otros derechos encajan- y ocasiona los desmoronamientos que, como intuye el art. 10.1 CE, pueden acontecer seguidamente.

\section{BIBLIOGRAFÍA DE ORIENTACIÓN}

Alvarez, I. El futuro de la mediación preprocesal. Madrid: Ed. La Ley, 2007. Alzaga, O. Comentario sistemático a la Constitución española de 1978. Madrid: Ed. Ediciones del foro, 1978.

Barcellona, P. et al. L'uso alternativo del diritto. Roma-Bari: Ed. Laterza, 3 vols., 1974. 
Bayet, A. Historia de la libertad de pensamiento, traducción de ArRuÑADA, M. Buenos Aires: Ed. Paidos, 1962.

Brimo, A. Les grandes courants de la philosophie du droit et de l'Etat. París: Ed. Pedone, 1968.

CArbonnier, J. Derecho Civil, traducción y «adiciones» de conversión al Derecho español de Zorrilla, M.M., vol.1/1. Barcelona: Ed. BOSCH, 1960-1970.

Darnstadt, T. La trampa del consenso, traducción de MZ. DE luco J.M. y estudio introductorio de Sosa, F. Madrid: Ed. TROTTA, 2005.

De Angel, R. «Constitución y Derecho de daños», Estudios de Deusto, vol. 55/1, pp. 173-220.

Delhaye, P. Permanence du droit naturel. Lovaina: Ed. Nauwelaerts, 1.960.

Desdentado A. et al. Seguridad Social: Manual de Formación. Madrid: Ed. Consejo General del Poder Judicial, 2002.

Duverger, M. Instituciones políticas y Derecho Constitucional, traducción de Ferrero J. y prólogo de Lucas Verdu, P. Barcelona: Ed. Ariel, 1962.

EsCARPIT, R. Teoría general de la información y la comunicación, traducción de Carbo, A. y Sanagustin, P. Barcelona: Ed. Icaria, 1981.

Fromm, E. et al. Humanismo socialista, traducción de Goligorsky, E. Buenos Aires: Ed. Paidos, 1980.

Garcia de Enterria, E. y Fernandez, T.R. Curso de Derecho Administrativo. Madrid: Ed. Civitas, 1984.

Goldmischt, W. La ciencia de la justicia. Madrid: Ed. Aguilar, 1958.

Gordillo, L.I. Constitución y ordenamientos supranacionales, prólogo de PERez Tremps P. Madrid: Ed. Centro De Estudios Politicos y Constitucionales, 2012. «El proceso de integración europea y la teorización de la dinámica comunitaria», Iuridica, vol. 2, 2005, pp. 47-80.

LEPP, I. La nueva moral, traducción de GARASA, D.L. Buenos Aires: Ed. CARLOS LOHLE, 1964.

LinZ, J.J. La quiebra de las democracias, traducción de Teran, R. Madrid: Ed. Alianza Universidad, 1987.

Lopez Aranguren, J.L. Etica. Madrid: Ed. Biblioteca Nueva, 1997.

Louis, J.V. El ordenamiento jurídico comunitario, traducción y edición de la Oficina de Publicaciones de la Comisión de las Comunidades Europeas, Bruselas-Luxemburgo, 1985.

Lucas Verdu, P. El sentimiento constitucional. Madrid: Ed. Reus, S.A., 1985.

Marina, J.A. y De la Valgoma, M. La lucha por la dignidad. Barcelona: Ed. Anagrama, 2000.

Maritain, J. Humanisme integral. París: Ed. AUBIER MONTAIGNE, 1936.

Movilla, C. y Zorrilla, M.M. «Protección judicial efectiva de las libertades», Estudios de Deusto, vol. 45/2, pp. 285-295.

Oehling, A. La dignidad de la persona. Madrid: Ed. Dykinson, 2010.

Peces Barba, G. La Constitución española de 1.978: Un ensayo de Derecho y Política, con la colaboración de Prieto, L. Valencia: Ed. Fernando Torres, 1981. 
Perelman, CH, Les notions a contenu variable en droit. Bruselas: Ed. Bruylant, 1984.

Poulantzas, N. Nature des choses et droit. París: Ed. Librairie Générale de Droit et de la jurisprudence, 1966.

REvel, J.F. El conocimiento inútil, traducción de Bochaca. J. y prólogo de TuSELL, J. Madrid: Ed. Espasa Calpe, 1993; El rechazo del Estado, traducción de Pujol, C. Barcelona: Ed. Planeta, 1984

Roubier, P. Droits subjectifs et situations juridiques. París: Ed. Dalloz, 1963.

Thery, H. Les groupes sociaux: ¿Forces vives? París: Ed. Editions du centurion, 1964.

Treves, R. Livertá política e veritá. Milán: Ed. Editions Della Communita, 1962. Zorrilla, M.M. «El Derecho Natural como técnica de racionalización», Sociología para la convivencia, pp. 153-178. Madrid: Ed. ZYX, 1966; «Modernidad y moralidad de la mundialización», Estudios de Deusto, vol. 50/2, pp. 181-196; «Del sometimiento al imperio de la ley a la modernidad del arbitraje», Estudios de Deusto, vol. 55/2, pp. 185-211; «Eficacia y justicia del orden natural de la equidad», Estudios de Deusto, vol. 57/2, pp. 255-302; «Servidumbre y grandeza de la mediación en el ámbito del Derecho Privado de la Unión Europea», Estudios de Deusto, vol. 58/2, pp. 299-319; «Voluntad transformadora del sindicato democrático», Estudios de Deusto, vol. 59/1, pp. 277-308; «Difusión extrajudicial del Derecho justo frente al reto del achicamiento del mundo», Estudios de Deusto, vol. 59/2, pp. 209-235.

RESUMEN: La indemnidad supone que el ordenamiento jurídico del Estado de Derecho debe estar exento de vacios que entorpezcan sus procesos de prosperidad o plenitud. La prosperidad deriva de desarrollar ciertos postulados constitucionales implícitos e idóneos para favorecer ese estado de cosas. Ello lleva al convencimiento de que el pluralismo politico ofrece una variedad de posiciones antagónicas o predilecciones ideológicas que, pese a su incompatibilidad transversal, se atemperan a la letra y/o el espiritu móvil de la las normas constitucionales. Cualidad que se armoniza con la presunción de justicia material de las normas de un ordenamiento jurídico que antepone ese carácter a la presunción tradicional de validez que se le reconoce. El examen comprende aspectos de la indemnidad -ausencia de daño o deterioro-actualmente exigibles $y$ necesitados de tutela. Se consideran los relativos a cuestiones especialmente actuales, como la constitucionalización del uso alternativo del Derecho, algunas manifestaciones de la indemnidad y la atención debidas al futuro de la persona humana como un bien cuya pérdida o menoscabo da derecho a una reparación social a cargo de los poderes públicos competentes para establecerla.

PALABRAS CLAVE: indemnidad, plenitud, exigencias constitucionales, pluralismo político, supremo valor de la justicia, manifestaciones especificas de la indemnidad, indemnidad del futuro personal.

TITLE: Aspects of indemnity in the Spanish Constitution of 1978. 
ABSTRACT: The indemnity supposes that the matter of the law of the sovereign State, must be exempt of hollows which obstruct its optimum of prosperity. The prosperity derives of developping some implied postulates which are apt to foment this state of the things. It makes know that the political pluralisme shows a variety of antagonic positions or ideologic predictions, apt, in spite of it, to respect the letter and the constitutional spirit. This quality is harmonious whith the praesumption of the material justice placed before the praesumption of validity own of the juridical rules. This work includes aspects of an especial actuality consisting in the alternative use of the law, the singular expressions of the indemnity and the attemption due to the future as a good whose reduction or loss must be repaired by the action of the public powers.

KEYWORDS: Indemnity, plenitude, constitutional exigencies, political pluralisme, supreme valor of the material justice, manifestations of the indemnity, indemnity of the personal future.

Recibido: 24.07.2013

Aceptado: 02.09.2013 